\title{
4. AZ ISKOLA MINT ISKOLASZERVEZET
}

\author{
BORSODI CSILLA NOÉMI
}

\section{Bevezetés}

Egy iskola hatékonyságát, az ott zajló munka eredményességét jelentős mértékben befolyásolhatja az adott intézmény szervezeti kultúrája, az adott kultúrában betöltött hely - mint kollektív elvárás - személyes megélése (azzal való azonosulás vagy épp ellenérzés) az egyes résztvevők részéről, továbbá ezek nyomán a kialakult/formálódó légkör, melyben az eredményességet célzó folyamatok zajlanak. Több élménye/elvárása/vélekedése lehet az egyes pedagógusoknak arról, hogyan is „müködik”/"müködjön” az iskola, hogyan, milyen elvek, illetve mely célok mentén kell(ene) közösen munkálkodniuk a pedagógusoknak, a vezetőségnek (illetve a teljes „iskolahasználói közösségnek”, mely esetében szintén szervezetikultúra-függő, milyen erős szálon kötődnek egymáshoz, és milyen mértékben tekinthetők a „közösség” részének az egyes tagok, mint például a szülő, a gyermek és a „hiányterületi” pedagógus vagy éppen a pedagógiai munkát segítő). Igen nehéz meghatározni, mit is jelent maga az iskolaszervezet kultúrája, hiszen a kultúra mindent átfogó jellege teszi nehézzé, hogy megragadjuk sajátosságait. Nem lehet élesen elkülöníteni a szakmai, pedagógiai és szervezeti működés mögött rejlő értékeket és meggyőződéseket (Serföző, 2005). Az iskola minden iskolahasználó (tanuló, tanár, diák) számára mást jelent, és még az egyes „csoportokon” belül (pl. tanulók körében) sem egységes a megítélése (hiszen van, aki egy „vidám helyként”, míg más „börtönként” gondol rá). A pedagógusok közül némelyek talán a szakmai együttműködés színterének, míg mások pusztán „munkahelynek” tekintik (Ollé, 2006). Megállapítható mindenesetre, hogy a légkört, az iskolahasználók iskolaközösségként való öndefinícióját mindig az adott szervezeti kultúra határozza meg, hiszen befolyásolja a pedagógusok és tanulók közérzetét (Serfőő, 2005).

\subsection{Tanulmányunk felépítése}

A szervezeti kultúra jelenségvilága igencsak átfogó, így szakirodalmi háttérelemzésünket általános szervezetelméleti alapozással együtt négy, kutatási kérdéseinket és hipotéziseinket, valamint azok vizsgálatát három nagyobb logikai egységre bontottuk. Szakirodalmi áttekintésünk szerkezete a következő:

1. szervezeti kultúra fogalmával kapcsolatos elméleti háttér,

2. a tanárok vélekedése a szervezeti kultúráról, 
3. a szülők bevonódottsággal kapcsolatos nézetei,

4. a tanárjelöltek közérzete, bevonódottsággal kapcsolatos helyzetmegítélése.

Kutatási kérdéseink ennél szélesebb körűek voltak, kitértek ugyanis a szülők és iskola kérdéskörén belül a szülők és osztályfőnök, valamint a tanulók és tanárjelöltek kapcsolatára. Jelentős átfedés volt a szervezeti kultúra és légkör, illetve a vonzó iskola kérdésköre között, így témánkból ennek okán emeltük ki pl. a tanulók és pedagógusok kapcsolatát.

\section{Az iskola mint szervezet}

Az iskola szervezeti kultúráját több forrás azonosítja a klímával. Ezekre e fejezetben nem térünk ki, hiszen azt kötetünk egy másik tanulmányában vizsgáljuk. A légkör és a (z iskola) szervezeti kultúr(áj)a közti kapcsolat ugyanakkor vitathatatlan, mivel a légkör fogalma alatt a szervezetben megélt komfortérzést, munkahelyi közérzetet együttesen értjük. A közérzet, légkör vizsgálata azonban minden esetben a szervezeten belül történik, és eltérő szervezetikultúra-típusokhoz eltérő klíma társulhat. A klíma befolyásolja továbbá a szervezeti kultúra alakulását, fejlődését is (Csapó és Csécsei, 2011; Golnhofer, 2006). Léteznek írott (Szervezeti és Mủködési Szabályzat), valamint íratlan - az intézmény kollektívája, közössége által formált és fejlesztett - szabályok, melyek az iskola egész arculatát meghatározzák. E szabályok segítenek a közösségben „élő és működő” embereknek, hogy átlássák, adott szervezetben mi a „jó”, mi a „rossz”. E normák általános és sok esetben nem tudatosult megjelenési formái bizonyos tartalmaknak és hiteknek, melyeket a szervezet tagjai - iskola esetében az iskola tanárai, dolgozói, tanulói és jelen esetben a tanárjelöltek - elfogadnak, követnek. Több kutató vitázott már azon, vajon az iskoláknak mint szervezeteknek van-e kultúrája. Azon is folynak a viták, hogy milyen szélesen értelmezhető, illetve hogy a tanulócsoportok szubkultúraként vagy a kultúra részeként említhetők-e, illetve hogy a teljes iskolahasználó közösséget belesorolhatjuk-e (Bruner, 1973; Woods, 1983). Létezik olyan megközelítés is, mely nem a tagok, hanem a szervezet működési struktúrája felől - szervezetelméleti megközelítésben - vizsgálja a kultúrát (Hoy és Miskel, 1987). Ez utóbbi statikus szervezetelméleti modellek megalkotását célozza, melyek az iskola világára nehezen értelmezhetőek, így - pusztán az elméleti háttér átláthatóvá tétele céljából - jelen tanulmányunk keretében nem vállalkozhatunk ezek bővebb kifejtésére, csak felsoroljuk azokat. Legismertebb közülük Harrison és Handy később továbbfejlesztett modellrendszere, mely a szervezetet minden esetben a vezető felől vizsgálja. Csapó és Csécsei e kultúratípusokat görög istenekhez hasonlítva mutatja be (Csapó és Csécsei, 2011). E tipológiák a következők: 
1. Klubkultúra (vezetőközpontú) - Zeusz isten,

2. Szerepkultúra - Apolló (a vezető és a beosztottak itt munkahelyi szerepük alapján kerülnek „felcímkézésre”),

3. Feladatkultúra - Athéné (a vezető és beosztottak feladatellátó személyek, a hierarchia csökkentésére való törekvés jellemzi),

4. Személyiségkultúra - Dionüszosz (minden egyes személyiség autonóm, kevéssé jellemző az együttmüködés, sok esetben, ha van is, csupán látszólagos, ugyanakkor magas szintü az autonómia).

Csapó és Csécsei, akik átfogóan vizsgálták mind a szervezeti kultúrát, mind a légkört, azon állásponton vannak, hogy önmagukban ezen kultúratípusok nem értelmezhetők, és nincsenek „tiszta típusok”. A kultúra fejlődését, az abban való szerepvállalás megélését, a közérzetet és azáltal a légkört is befolyásolja a környezet (ez inkább az utóbbit, így ennek részleteit nem tárgyaljuk), valamint a történetek, hagyományok, történések.

Izgalmas - bár szintén többé-kevésbé statikus - kultúraelméleti megközelítés Hofstede hagymamodellje (mely ha belegondolunk, a pedagógussá válás korthageni modelljére emlékeztet).

E megközelítés - nagy vonalakban - a következőket foglalja magában:

1. eleve elfogadott feltételezések, vélekedések, nézetek, hitek,

2. értékek (a szervezet deklarált értékrendje, pl. Szervezeti és Müködési Szabályzat),

3. mítoszok, hősök, szimbólumok (a szervezet alapvető és rejtett értékei, értékrendje; követendő és elfogadott szerepmodellek, elvárások; hősnek tekinthetők nem csupán a szerepmodellek, hanem az intézmény kiemelkedő, szervezeti célok elérésében élen járó, innovatív pedagógusai is),

4. normák, szabályok, rituálék (szervezet szokásai, mintái) (Csapó, Csécsei; 2011; Golnhofer, 2006; Hofstede, 1991).

Hofstede e modellt később fiával együtt a következő módon fejlesztette tovább: 


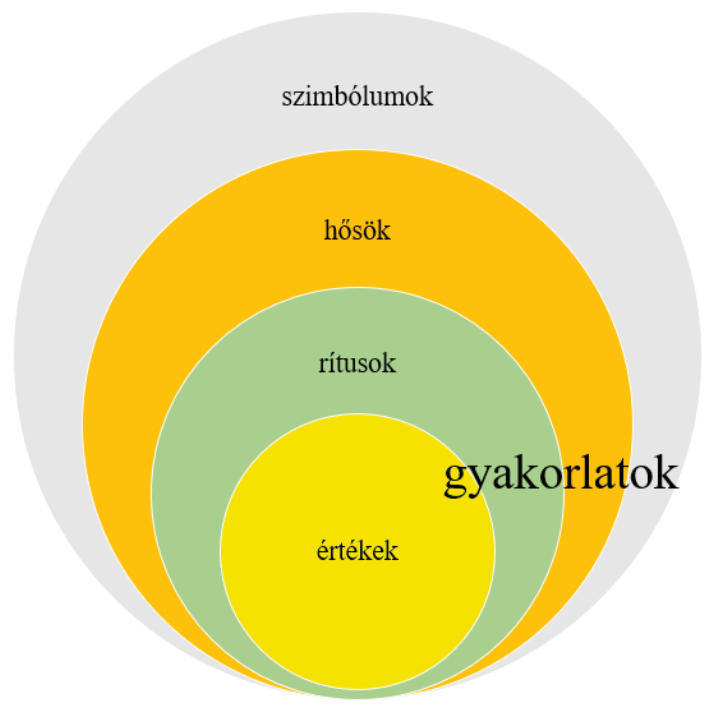

\section{1. ábra: A kultúra hagymamodellje. (Forrás: Hofstede és Hofstede, 2008)}

E továbbfejlesztett változat (1. ábra) jól illusztrálja a szervezeti struktúra dinamikus mivoltát, és általános érvényűnek, bármely szervezettípusra érvényesíthetőnek tünik. A gyakorlatok azok, melyek a hagyma egyes elemeit összekapcsolják, azok tartják életben és működtetik a szervezetet, legyen szó tantárgyi tartalmakra vonatkozó oktatási stratégiákról vagy pedagógiai jó gyakorlatok kipróbálásáról és alkalmazásáról, esetleg valamely iskolai hagyomány kialakításáról.

Bár jelen munkánknak nem célja, igen izgalmas megközelítés ez, hiszen a szervezeti kultúra a pedagógussá válás folyamatában „valahol” tartó személyekből és diákjaikból áll, valamint szülőkből, akik szintén saját vélekedéseik mentén élik meg az iskolához tartozást. Számunkra e modell annyiban érdekes, hogy mind a tanárjelöltek szervezeti kultúrához való viszonyát, mind a pálya különböző szakaszán álló pedagógusok vonatkozó reflexióit vizsgáljuk.

\subsection{A tanárok közérzete a szervezeti kultúrában}

A pedagógusok a tanári közösségben egyszerre több feladatot is elláthatnak. Tagjai természetesen a nevelötestületnek, egy tantárgyat oktatók csoportjának, egyéb munkaközösségeknek. (Tagjai lehetnek jelen esetben egyéb, pl. osztályfőnöki, illetve gyakorlóiskola esetében vezetőtanárok csoportjának is.)

Az osztályfőnöki szerep az egyik legismertebb pedagógusi szerep a köznevelési rendszerben. Már az 1850-es évektől kitüntetett szerep jut az osztályfőnököknek, illetve a belőlük szerveződött osztályfönöki munkaközösségnek. Az osztályfönökké váláshoz többnyire szükség van néhány év tanítási gyakorlatra, ugyanis a kezdő tanár a „praxissokkal” birkózva nehezebben 
tud megbirkózni az osztályfőnöki feladatokkal. Az osztályfőnök egyensúlyoz a szülöi elvárások és a gyermek teljesítménye között, miközben mindvégig a gyermek érdekét tartja szem előtt. Ö az, akinek - természetesen a szülők mellett, de olykor még náluk is erőteljesebben - kötelessége ismerni a gyermekek szociális hátterét, tanulmányi eredményességét, kapcsolatát szüleivel, osztálytársaival. Lényeges, hogy a diákok merjenek fordulni osztályfönökükhöz, és hogy a szülők is „társként” tekintsenek rá. A szülők elvárják, hogy ha baj történt, tájékoztassa őket. Ö tehát a nevelés „mindenese”, akikre mind a szülők, mind a tanulók egyaránt számíthatnak, és aki emellett természetesen a tanári kar tagja, valamint az osztályfőnöki, szaktanári és esetleg egyéb munkaközösség(ek)é is (Karlovitz, 2011; Szekszárdi, 2002).

Szekszárdi Júlia kutatása során azt találta, hogy az osztályfőnökök jellemzően nem töltik be „hagyományos” funkcióikat, csökkent az osztályfönök és osztálya egymáshoz való kötődésének ereje (Szekszárdi, 2002). Érdekel minket mindezek fényében, hogy vajon az egyes pedagógusok tanulóközösségben gondolkodnak-e, vagy inkább munkahelyben, pozícióban, feladatkörökben, hogy a pedagógusok csoportja, a kollektíva milyen mértékben alkot egységes egészet, kik azok, akik között az együttműködés a legszorosabb (egyes pedagógusközösségek, vagy a szülők is az „iskolaközösség”, a tanulószervezet tagjai-e), peremhelyzetinek tekint-e az iskola valamely foglalkozási területeket, esetleg a tanárjelöltekkel való együttműködés tűnik nehézkesnek. Mindezen kérdésekre szeretnénk kutatásunk során megkapni a választ, leszögezve, hogy az önfejlesztő iskoláknak tanulószervezeteknek kell lenniük. Az egyéni továbbképzéseken való részvétel önmagában nem elég, ha tudásmegosztás nem társul hozzá.

A pedagógusi sikeresség, illetve azon belül a tanulói teljesítmény, jó közérzet egyfajta „csapatjáték” eredménye, nem az osztályfönök „szélmalomharca” vagy magányos pedagógusok küzdelmének eredménye. Ha egy „problémásnak” titulált gyermekkel kapcsolatban az egy osztályban tanítók csoportja megbeszélést tart, majd elkezdenek valamennyien kiemelten figyelni a tanulóra, bevonják közösségfejlesztő aktivitásokba, a „probléma” egyre kevésbé lesz észrevehető (Karlovitz, 2011). Köztudott, hogy a pedagógusok közérzete meghatározza munkájuk eredményességét. Kölcsönhatásban áll a tanulói eredményességgel és a tanulók körében való kedveltséggel (Füzi, 2007, 2011, Suplicz, 2007, 2012). A tanári eredményesség azonban nem kizárólag a diákokkal való közös munka, hanem a kollegiális együttműködés, a szülők társként való bevonása és egyfajta speciális, közös, hálózati tanulás gyümölcse is. Emellett figyelembe kell vennünk, hogy az iskolai munka eredményessége nem csupán a szervezeti kultúrától, illetve az azon belül elfoglalt helytől függ, hanem szerep-, státuszfüggő is. Ehhez elengedhetetlen a szervezeti kultúra eredményességének vizsgálatakor a „hiányterületi” pedagógusok megítélésének, munkakörülményeinek vizsgálata is. Ők a tanárokkal együttmüködve, őket segítve, esetenként tanári szerepben is helytállva segítik az intézmény munkáját.

A tanulókra való odafigyelés, a szülőkkel való együttműködés és gyakorlóiskoláról lévén szó a tanárjelöltekkel való együttműködés sikere mind kiemelt szempontként kezelendő. 


\subsection{A szülők és az iskola}

A gyermekek iskolai teljesítményének előmozdításával kapcsolatban felmerülő egyik leggyakrabban említett tényező az iskola és a család együttműködésének mértéke, azaz a szülői bevonódottság, mely talán idegenül hat, ugyanakkor az angolszász irodalomból ismert „involvement” kifejezést talán leginkább ez fedi le, mélyebb tartalmat hordoz ugyanis magában, mint az egyszerű „részvétel” kifejezés, közelebb áll angol megfelelőjéhez, mely a szülői bevonódás alatt a különböző intézményi programokon való részvételen túl egyfajta belső elkötelezettséget, pozitív attitűdöt, motiváltságot jelent az iskolával kapcsolatos tevékenységekben. A szülői bevonódás fejlesztése régóta hangoztatott célkitűzés a szakmai közvélemény körében nemzetközi szinten, és a fejlett országok oktatáspolitikájában számos erre vonatkozó akcióterv került kidolgozásra és megvalósításra.

A szülők iskolai életbe való bevonódottságának azonban mindig vannak ellentmondásos vonatkozásai. Gondoljunk az iskolai életben aktív szülőkre, akik részt vesznek minden rendezvényen, ott vannak minden szülői értekezleten, fogadóórán, illetve felkeresik a pedagógusokat, segítenek a munkákban, tagjai a szülői testületeknek. Az esetek nagy részében mind ugyanazok a szülők. Ugyanazon gyermekek szülei, akik ezáltal mindig előnyösebb helyzetben vannak, mivel szüleik elsősorban saját gyermekeik érdekeit szem előtt tartva vonódnak be az iskolai életbe, nem feltétlenül minden gyermek javát akarva (F. Lassú és mtsai., 2012).

Mindez jelen kutatásunk vonatkozásában lényeges, hiszen figyelembe kell vennünk a szülők és a tantestület, valamint azon belül a szülők és az osztályfönök kapcsolattartását, együttműködését, a szülők iskolaszervezetben való részt vállalását vizsgálva. A szülők célja lehetséges, hogy gyermekük önérvényesítésének támogatása. Ennek alárendelve keresheti fel az osztályfönököt vagy egyéb pedagógusokat. Mi azt vizsgáljuk, vajon jellemző-e, hogy a pedagógusok a szülői értekezleteken, fogadóórákon túl egyéb fórumokon is megkeresik a pedagógusokat, melyek a legjellemzőbb megnyilvánulási formái a szülői bevonódásnak.

A szakirodalom szerint maga a szülői értekezleten, fogadóórán való részvétel is vegyes megítélést kap mind a szülők, mind a tanárok nézetei szerint. Némelyek a „problémás gyermekek” szüleinek osztályfönökkel, pedagógusokkal való megbeszélésének színtereként, mások az adott rendezvényen való részvételt „kötelességként” értelmezik.

Azt mindenképpen meg kell állapítani, hogy e rendezvények önmagukban semmiképpen nem lehetnek elégségesek a szülő és pedagógus közti érdemi kommunikációra, ugyanakkor a szakirodalom arra is kitér, hogy a pedagógus jelentős része képtelen érdemben felkészülni a szülők pedagógiai értékelő, munkafegyelemre vonatkozó, valamint egyes rendezvények megszervezésére irányuló munkán túli kéréseire, kérdéseire. A pedagógusok és szülők többsége is kevéssé érzi szorosnak a pedagógus-szülő együttműködést. (Hegedüs és Podráczky, 2012) A szülői értekezletektől való szülői távolmaradást - melyek olykor túlzottan „rituálisak”, formalizáltak mind a szülők, mind a pedagógusok szerint, és amelyet mindkét fél jellemzően 
nyűgnek tekint - a pedagógusok jellemzően a „szülöi érdektelenségnek” tulajdonítják. Úgy vélik, javarészt azon szülők nem járnak el a fogadóórákra, szülői értekezletekre, akiknek a gyermekével „leginkább baj van”. A pedagógusokra jobban jellemző, hogy úgy érzik „baj van a szülőkkel”, míg a szülők úgy gondolják, abban az esetben keresik fel az iskolát, pedagógust, ha szükség van arra, pl., ha romlott a gyermek érdemjegye, vagy ha beírást találnak az üzenőfüzetben. Természetesen több szülő véli úgy, hogy ők maguk, a szülők a hibásak, saját időhiányuk az oka annak, ha a kommunikáció nem gördülékeny, és a pedagógusok „mindent megtesznek” annak biztosításáért. Olyan szülői nézetek is ismeretesek, melyek előtérbe helyezik a spontán beszélgetéseket, kapcsolatépítést a pedagógusokkal, melyek nem kizárólag a tanulói teljesítménnyel vagy éppen rendezvényszervezéssel kapcsolatosak.

Azt is mérlegelni kell, hogyan vélekedik az iskola (illetve az egyes pedagógusok) magáról az iskolaközösségről, kiket sorol ide, és hogyan vélekedik minderről a szülő. A pedagógusok és szülők között egyfajta „nevelési partnerség” kialakítására kell törekedni (Perlusz és mtsai., 2012).

Rövid elméleti áttekintésünkben a tanárjelöltek helyzetével, közérzetével kapcsolatos szakirodalmi előzményeket mutatjuk be, hiszen a gyakorlóiskola, szakmai fejlesztő iskola életének ők is részesei. Kutatást folytattunk ugyanis a konkrét iskola vonatkozásában annak kapcsán, hogy a tanárjelöltek milyen mértékben érzik magukat a kollektíva tagjának, illetve őket milyen mértékben sorolják az iskola közösségének tagjai közé a pedagógusok, mely feladatokba vonják be őket, és melyek azok, amelyekben esetlegesen hiány mutatkozik.

\subsection{A tanárjelöltek közérzete az iskolaszervezetben}

Mindenekelött érdemes munkánk tanárjelöltek iskolaszervezetben értendő közérzetét elemző fejezetének kezdetén - egyfajta értelmezési keretként - leszögeznünk, hogy szerepük megítélése kapcsán számos kérdést szükséges tisztázni: Tanár már vagy hallgató? A tanár szerepét gyakorolja vagy a gyakorlaton lévő hallgatóét? Hogyan definiálja saját helyzetét? Mit jelent a tanárjelölti lét? Hogyan képes egy tanárjelölt „ideig-óráig” bekapcsolódni az iskolaszervezetbe? Kiket tekint e munkájában közvetlen társainak? E kérdésekre jelenleg ismert elméleti válaszok megadását kíséreljük meg tanulmányunk e részében.

A tanárjelöltek közérzetéről, szervezeti kultúrába történő beilleszkedéséről, valamint általánosságban véve a tanári szerepazonosulásukról (beleértve természetesen a szervezeti kultúrában elfoglalt helyet) ez idáig viszonylag kevés szakirodalom született, mivel e terület vizsgálata még igencsak kezdetleges. A kutatások többsége inkább a tanárjelöltek belépési vélekedéseinek szerepét vizsgálja. Szivák Judit (2003) úgy gondolja, a tanári vélekedéseknek, önismeretnek, majdani (ön)reflektív gondolkodásnak az alapjait a pedagógusképzésbe való bekerülés elött teszik le a hallgatók. A felsőoktatás eredményessége (melyben természetesen az elméleti oktatás mellett kiemelt szerepe van a gyakorlati feladatoknak) döntő szerepet játszik a hatékony tanárrá válásban. A felsőoktatás a hallgatók előzetes elképzeléseit segít 
megismerni, feltárni, hiszen ezek határozzák meg, hogy mit tartanak fontosnak, mit vallanak magukénak a képzés során tanultakból, mivel képesek azonosulni, így képezve alapját a gyakorlati munka érdemi megvalósításának (Szivák, 2003). Levonhatjuk tehát a következtetést, hogy a felsőoktatás és a gyakorlóiskola együttműködése kiemelt szerepü a hallgatók fejlesztésében. (Felmerül a kérdés: mi tehát maga az iskolaközösség? A felsőoktatási hallgatók részesei-e annak?) Egyfajta szűrőt, a „naiv nevelési nézetek” egy lényeges faktorát jelentik tehát a tanulóként átélt tapasztalatok. Ezek minden esetben egyéniek, így a személyre szabott fejlesztés során ezekre kell alapozni.

A tanárjelölti nézetek szerepe jelen munkánk során lényeges lehet, hiszen ezek mentén igyekszik a hallgató érdemi munkát folytatni a tanulókkal. E mentalitása által alakulhat ki kép a gyakorlóiskolai vezetőtanárban is róla, befolyásolva együttműködésük hatékonyságát. Amennyiben közérzetét nem a pedagógusi, sokkal inkább a hallgatói öndefiníció hatja át, ha kevéssé érzi magát a kollektíva (ideiglenes) tagjának, úgy az kihathat a tanulókkal való együttmüködésének hatékonyságára is.

\subsection{A tanárjelöltek és az autonómia biztosítása}

Komlósi Ákos már 1987-ben elörevetített több majdani kutatási területet, így pl. a tanárrá válás aktuális állapotát másodéves tanár szakos hallgatók esetén, bemutatva, hogy a folyamat fejlődési szakaszokra és így fejlesztési feladatokra tagolható a tanárképzés részéről, a pályakezdés előtti időszakról, arról a gyakorlatról, mely megelőzheti a már tanárként megélt „valóságsokkot”, igaz, lényegesen kisebb felelősség, nagyobb támogatás és még hallgatói szerep mellett. Komlósi tehát a tanárjelölt definíciója kapcsán a „hallgatói szerep” mellett „teszi le a voksát”, nem térve ki a tanárjelöltek szerepazonosulására. Előrevetítette viszont a sikeres és sikertelen tanár jellemzőinek kutatását, hiszen említést tesz azon „evidenciáról”, miszerint a nevelési folyamat minősége (a pedagógiai interakció) nagymértékben függ az abban részt vevők személyiségétől, interakciós jellemzőitől. A sikeressé válás első lépcsőit a tanárjelölt teheti meg, és ebben is jelentős szerepe lehet a kollektívának, különösen, ha a tanári énhatékonyságot a kollégákkal történő együttmüködés során megvalósítható kollektív hatékonyságként értelmezzük. E nézőpontot már 1977-ben felvetette Bandura is, aki elkülönítette az egyén énhatékonyságát a kollektív hatékonyságtól (Bandura, 1977. 203). Ez utóbbi témáról több szerző is ír, kiemelve, hogy az nem más, mint a csoport tagjainak értékítélete a csoport képességeiről, melyek meghatározzák, hogy a csoport milyen célokat tűz ki maga elé, és mennyi erőt, energiát fektet azok elérésébe, valamint kudarc esetén megmarad-e a csoport összetartása, vagy erodálódik. A magas kollektív hatékonyságú csoportok nagyobb teljesítményre képesek, és nagyobb az összetartásuk, mint az alacsony kollektív hatékonyságú csoportoké. A közös tudás, a közös felelősség, a többszörös kapcsolódások a szervezeten belül, a kölcsönös függőségi viszonyok, ezek 
mind megteremtik az egyének személyes hatékonysága és a szervezet eredményes tevékenysége közötti kapcsolatot (Zagyváné Szücs, 2019). A közösség hatékonysága tehát nem más, mint egy adott társadalmi egység - mely lehet egy család, csoport, szervezet vagy éppen közösség - itéleteinek összessége arra vonatkozóan, hogy mennyire hatékonyan tud tevékenykedni egy adott területen (Caprara és mtsai., 2006; Zagyváné Szücs, 2019). Egy közösség kollektív hatékonyságába vetett hite azonban nem egyenlő a közösséget alkotó egyének énhatékonyságának az összességével (Bandura, 2001. 266; Zagyváné Szücs, 2019). A közösség saját hatékonysága erősen hat a közösséget alkotó egyének énhatékonyságára, és nagymértékben befolyásolja a munkával való elégedettséget is (Zagyváné Szücs, 2019). Nem nehéz mindezek ismeretében belátni, hogy a pedagógussal szemben nem csupán a kollegiális együttműködés jelenik meg elvárásként a legtöbb kutatás tanulságai szerint, hanem - amennyiben a tanulók kollektív hatékonyságát mint teljesítménynövelő tényezőt vesszük figyelembe, úgy nem nehéz leszűrni a következtetést, miszerint - a tanulói közösségek építésével kapcsolatban is lényeges feladatai vannak a tanároknak, illetve tanárkollektíváknak.

A tanulókkal való hatékony kommunikáció tulajdonképpen maga a nevelési folyamat minősége, hiszen a tanulókkal folytatott pedagógiai kommunikáció elsődleges célja a nevelés-oktatás hatékonyságának fejlesztése. Akit kedvelnek a tanulók, az képes azt érdemben megvalósítani, akit nem, az olyan, mintha munkája során számtalan falba ütközne. Ma is aktuális kérdést, a tanárjelöltek bemeneti, illetve képzés ideje alatt meglévő nézeteinek szerepét is vizsgálja a szerző, a jelenlegi kutatásoktól némiképp eltérő módon. Nem nevezi meg konkrétan, hogy „bemeneti nézetek” is léteznek (ahogy azt később Falus Iván teszi), és ezek módosulnak, fejlődnek (nem pedig megszűnnek) a tanárképzés és tanárrá válás folyamán (Falus, 2001, 2002, 2004), hanem inkább kérdésként veti fel a hallgatók szimuláció során tanúsított viselkedése kapcsán, hogy vajon van-e viselkedésükben „nevelési elv”, „pedagógiai szemléletmód”. Természetesen igazi pedagógiai tudatosságról, tanulókkal való hatékony kommunikációról másodéves hallgatók esetén szó sem lehet, hiszen a jó tanárdiák kapcsolathoz idő és tanári szerep szükséges. (A hallgatóról a diákok tudják, hogy nem tanár, és ő maga sem érezheti magát annak, csak ha már kézhez kapta a diplomáját, és „igazi” gyakornokká válik.) A „pedagógiai szemléletmód” alatt Komlósi azonban nem a hallgatók kognitív sémáját érti, mely tanulóként átélt tapasztalatokon alapszik, sokkal inkább kezdetleges vezetési stílusra gondol. A szerző által leírt pedagógiai szemléletmódok közül - U. Komoly Juditáltal továbbfejlesztett kategorizálás nyomán - a restriktív (korlátozó, illetve az agresszív) megfeleltethető az autokratikus, a kooperatív a demokratikus, az inerciás (és az indifferens) a laissez faire vezetési stílusnak. Komlósi utal arra is, hogy a főiskolai hallgatók úgy vélik, munkájukat „pedagógiai tudatossággal” végzik. (Az idézőjel vélhetően arra utal, a tudatosságuk gyakorlat híján, a tanárrá válás kezdetén még nem lehet valós.) A szerző úgy véli - ezt később Lénárd Sándor is megerősítette szülői naiv nézeteket 
kutatva -, hogy (ahogy a tanárjelöltek, úgy) a szülők esetén igaz, hogy nem teljes mértékben magabiztosak az ítéleteik pedagógiai döntéshelyzetekben, nehezen találják meg a „megfelelő nevelési stílust" (Lénárd, 2003). Ennek oka a pedagógiai tudatosság hiánya, kiforratlansága lehet, illetve a nem teljes mértékben célirányos nevelési tervek (Komlósi, 1987). Tovább árnyalhatja a képet, hogy a „tanárság gyakorlásához” közvetlenül kötődő mindennapi feladatokat, pl. a tervezést, a tanulásszervezési mód tudatos megválasztását a tanárjelöltek nem minden esetben képesek érdemben megvalósítani. Nilssen (2010), Norman (2011) és Graff (2011) rámutat, hogy a tanárjelöltek a tanítási folyamat tervezésének és érdemi megvalósításának összetettségét még nem értik teljes mértékben, így a gyakorlati munka számukra megterhelő lehet: a hallgatók vagy magára a tananyagra, tananyagtartalomra vagy a tanulókkal való kommunikáció megvalósításának lehetőségeire tudnak figyelni a pedagógiai tervezés során (Nilssen, 2010; Norman; 2011; Graff, 2011; Molnár, 2015), a kettő egyszerre már nehézséggel jár számukra.

Mindezen tényezők figyelembevétele elengedhetetlen akár a tanárjelöltek autonómiaérzetének, akár a tanárjelöltek és tanulók hatékony kommunikációjának vizsgálata során. A gyakorlóiskola, pontosabban a vezetőtanár és/vagy a teljes kollektíva (e kérdés megválaszolhatósága szintén szervezetikultúra-függő) szerepe abban rejlik, hogy támogassa a tanárjelöltet pedagógussá válása elején, miközben az „önálló” tanár szerepét gyakorolhatja. A gyakorlóiskola felelőssége a támogatás és önállóság biztosításában megteremtett egyensúly megvalósítása.

E rövid elméleti háttér határozta meg sokrétủ, átfogó vizsgálatunk irányvonalát, melyben - a fenti fejezeteknek megfelelő szempontok és sorrend alapján - a tanárjelöltek szervezeti kultúrában definiálható közérzetét vizsgáltuk, szem előtt tartva fentiekben vázolt szerepidentitás-beli és a nézetrendszer kiforrottságára vonatkozó nehézségeket, valamint a szülők bevonódottságérzetét az intézmény szervezeti kultúrájába, figyelembe véve a szakirodalmak által a bevonódottság megítélését nehezítő körülményeket.

\section{A kutatás}

\subsection{Kutatási céljaink}

A fent bemutatottak átfogó vizsgálatára vállalkoztunk 2015 és 2017 között lefolytatott vizsgálatunk során a gyakorlóiskola vonatkozásában.

Kutatásunk céljainak tekintettük:

1. A gyakorlóiskola életében aktuálisan részt vevő tanárjelöltek és szülők bevonódottságérzetének, illetve a pedagógusok velük kapcsolatos nézetrendszerének vizsgálatát, ezek 
összefüggéseinek feltárását, mivel ekkor annak meghatározására törekedtünk, vajon hol tart a konkrét intézmény a „tanuló szervezetté” válás útján.

2. A pedagógusok közötti csoportösszetartás főbb motívumainak, lényegesebb közösségformáló erőinek, valamint a munkavégzést segitő és gátló erőknek a feltárását, valamint annak vizsgálatát, hogy melyek a hatékony munkavégzést segitő és az azt esetleg akadályozó erők.

3. Arra vonatkozó kérdés megválaszolását, hogy az adott iskola mint szervezet hogyan funkcionál, milyen mértékben tekinthető egységes iskolaközösségnek, melynek tanulók, szülők, diákok, tanárok, egyetemi oktatók egyaránt tagjai.

\subsection{Kutatási kérdéseink}

Kutatási kérdéseinket a következő fő dimenziók mentén határoztuk meg, melyekhez kutatási kérdéseinket és kapcsolódó hipotéziseinket is rendeltük:

1. A tanárok vélekedése a szervezeti kultúráról

Vajon iskolaközösségként értelmezi magát a gyakorlóiskola közössége?

1.1. Vajon kiket soroltak ide a pedagógusok?

1.1.1. Az iskolaközösség részének tekintette-e a tanári kar a szülőket?

1.2. Mely szempontok mentén határozták meg a pedagógusok identitásukat? (Pl. a konkrét intézmény szervezeti kultúrája vonatkozásában arra szerettünk volna tehát választ kapni, hogy a hasonló érdeklődés, esetleg az egy osztályban tanítók vagy a szimpátián alapuló baráti közösségekhez tartozás, a szakvezetői mivolt, netán az egy képzéstípus vagy egyéb tényező az, mely öndefiníciójukat leginkább meghatározza.)

2. A szülők bevonódottságérzete, kapcsolata a pedagógusokkal

Vajon a szülők részeseinek érzik-e magukat az iskola mindennapjainak?

2.1.Általában kommunikálnak-e a pedagógusokkal, vagy csupán valamely konkrét okból teszik-e azt?

2.2.Jellemző-e, hogy élnek az internet adta kommunikáció lehetőségeivel, vagy maradnak a „hagyományosabb” formáknál?

2.3.Az együttműködés vagy egyfajta, a tanulókkal kapcsolatos ellenőri szerep jellemzi-e az osztályfőnök és a szülők kapcsolatát?

2.4.Az osztályfőnök jellemzően szorosabb kapcsolatban áll-e a szülőkkel, mint az egyes osztályokat tanító többi pedagógus?

3. A tanárjelöltek bevonódottságérzete

Milyen mértékben érzik a tanárjelöltek úgy, hogy bevonta őket az intézmény a mindennapjaiba? 
3.1. Általánosságban elmondható-e, hogy a hallgatók az intézmény működésének több aspektusát láthatták?

3.2.Érezték-e, hogy fejlődtek a pedagógusokkal, szülőkkel való együttműködés terén?

3.3. Úgy gondolták-e, hogy tagjai lehettek a nevelőtestületnek mint szakmai közösségnek?

3.4. Tartották-e a hallgatók a kapcsolatot oktatóikkal gyakorlataik ideje alatt?

\subsection{Hipotéziseink}

A következőknek megfelelően fogalmaztuk meg hipotéziseinket, minden egyes kérdéshez a megfelelő számú, adott esetben akár több alhipotézist rendelve.

\subsubsection{A tanárok szervezeti kultúrára vonatkozó nézeteivel kapcsolatos hipotézisünk:}

H1: A gyakorlóiskola közössége alapvetően iskolaközösségként definiálja magát. E feltevésen belül további alhipotéziseket különítettünk el:

H1.1: A pedagógusok a szülőket, pedagógusokat, diákokat az iskolaközösség részének tekintik, nem állítják azonban ugyanezt az egyetemi oktatókról és a tanárjelöltekről.

H1.1.1: A szülőkkel kapcsolatban a tanárok úgy nyilatkoznak, hogy részei a közösségnek, ugyanakkor a szülők szerint a kapcsolattartás elsősorban az osztályfönökökre korlátozódik. H1.2: Nem jellemző, hogy a pedagógusok törekednének a szakmai együttműködés tantárgyi koncentráció formájában történő megvalósítására.

\subsubsection{A szülők bevonódottságérzetére vonatkozó hipotézisünk és annak alhipotézisei:}

H2: A szülők bevonódottságérzetét egyfajta ambivalencia jellemzi.

H2.1: A szülők a „hagyományos” pedagógus-szülő kapcsolat hívei, és csupán a szükséges (azaz általuk annak ítélt, minimális, legalapvetőbb) kommunikációra szorítkoznak.

H2.2: Elképzelhető, hogy Facebook- vagy egyéb közösségi csoportokat alakítanak ki pedagógusok és szülők, ám ezek csekély mértékben népszerüek.

H2.3: Az osztályfőnök jellemzően egyfajta ellenőri szerepben van jelen. (Pl. fegyelmezési problémák esetén keresi a szülőket.)

H2.4: Az osztályfönök az, aki szoros kapcsolatot ápol a szülőkkel, míg a többi pedagógusra ez kevésbé jellemző.

\subsubsection{A tanárjelöltek bevonódottságérzetével kapcsolatos hipotéziseink}

H3: A tanárjelöltek iskolaközösséggel kapcsolatos bevonódottságérzete kívánnivalót hagy maga után, mivel az csupán némely dimenzió mentén fejlődött. Jelen hipotézisünkön belül további alhipotéziseket fogalmaztunk meg:

H3.1: A tanárjelöltek jellemzően csupán tanórákat hospitálhattak és tarthattak, ugyanakkor 
a szervezet életébe csekély mértékben tudtak bevonódni (nem vehettek részt értekezleteken, nem kapcsolódtak be másik iskolaszint munkájába).

H3.2: A tanárjelöltek és a szülők közt nem fejlődött a kapcsolat.

H3.3: A hallgatók elsősorban a vezetőtanárral, illetve a tanulókkal építették kapcsolatukat, a nevelőtestület többi tagjával erre kevesebb lehetőségük volt.

H3.4: Az egyetemi oktatók a tanárjelöltekkel tartották a kapcsolatot a gyakorlóiskolai tanítási gyakorlataik ideje alatt.

\section{Kutatási eredményeink}

Jelen fejezetben először a pedagógusok szervezeti kultúrában elfoglalt helyével (4.1), majd a szülők (4.2.), illetve a tanárjelöltek (4.3.) közösséghez, iskolaszervezethez tartozásával kapcsolatos eredményeket mutatjuk be.

\subsection{A pedagógusok helye az iskolaszervezetben}

Azt találtuk, hogy a gyakorlóiskola pedagógusai elsősorban olyan iskolaközösséggel kapcsolatban gondolkodnak, melynek diákok, szülők, hallgatók, oktatók is részei. (Erről bővebben lásd. 5. fejezet $A z$ iskola légköre, 5. 2. ábra.)

Az érvényes válaszadók több mint 66\%-a állítja ezt.

Ennek oka azonban lehet, hogy úgy vélik, „ezt várjuk tőlük”, ezért jelen kérdést egyéb vonatkozó tartalmakkal is igyekeztünk vizsgálni. Az mindenesetre érdekes, hogy mindössze 1 ember gondolja úgy, hogy a gyakorlóiskola tanárok-diákok-hallgatók-szülők együttmüködését jelenti, ám amennyiben ugyanezen tagokat mint iskolaközösségi tagokat neveztük meg, már 11-en gondolták úgy, hogy helytálló a válasz.

\subsubsection{Mikrokultúrák, csoportalakító tényezők a pedagógusi közösségben}

Mivel az általunk megkeresett iskolában két különálló színtéren áll egy-egy intézményrész, így eredményeinkben ez is megjelent mint csoportalakító közösség, bővebben ennek részleteire nem térünk ki, annyit azonban érdemesnek látunk megjegyezni, hogy ez annyiban lehet lényeges, hogy a több épületből vagy tagintézményekkel is rendelkező iskolák esetén érdemes odafigyelni az ezzel járó esetleges kihívásokra. (A két épületnek a klíma szerepében betöltött funkciójáról bővebben $A z$ iskola légköre c. 5. fejezetben írunk.) Egyértelműen megállapítható, hogy a szaktanári munkaközösség $(\mathrm{N}=55)$ a legerőteljesebb összekötő kapocs a pedagógusok $(\mathrm{N}=95)$ számára. Ezt lényegesen lemaradva követi az azonos képzési formában dolgozók közössége $(\mathrm{N}=38)$, valamint a szimpátián alapuló baráti közösségek $(\mathrm{N}=38)$. Az azonos osztályban tanítók csoportját mindössze 17 pedagógus ítéli lényeges összetartó erőnek. 
Beosztás függvényében vizsgálva azt találtuk, hogy az osztályfönökök csoportját az általános iskolai tanítók körében ( $\mathrm{N}=16)$ senki nem választotta, ahogyan a vezetőtanítók ( $\mathrm{N}$ = 4) közül sem; az általános iskola felső tagozatán tanítók közül ( $\mathrm{N}=15)$ mindössze egy személy, ugyanakkor a vezetőtanárként dolgozó általános iskolai tanárok $(\mathrm{N}=10)$ közül egy sem. „Legtöbben”, azaz 3-3 fö a középiskolai tanárok közül ( $\mathrm{N}=27)$, illetve a szakértő vagy szaktanácsadó $(\mathrm{N}=26)$ beosztású pedagógusok közül gondolják úgy, hogy ez lenne a leglényegesebb közösség számukra, míg vezetőtanárként dolgozó társaik esetében $(\mathrm{N}$ = 16) csupán 1 fó vélekedik így.

A szaktanári munkaközösség, mely a legnépszerübb közösség, az általános iskolában ( $\mathrm{N}=16)$ a legkevésbé tünik kiemelt szerepünek, mivel csupán 3 fö jelölte meg, vezetőtanító társaik közül $(\mathrm{N}=4) 1$ fö. Ennek okai a tanítói szerepben rejlenek, hiszen ők nem definiálják önmagukat szaktanárként. A szaktanárként valóban helyt állók között azonban már teljesen más az arány, így mondhatni némiképp a tanítók - akik nem szaktanárok, bár kétségkívül vannak saját, általuk oktatott műveltségi területeik - azok, akik „lehúzzák” az így is igen nagy százalékban történő megjelölést. A felső tagozatban tanítók $(\mathrm{N}=15)$ körében 8 fó, vezetőtanár társaik körében $(\mathrm{N}=10)$ szintén 8 fö (itt a legmagasabb az arány), a középiskolai tanárok közt $(\mathrm{N}=27) 19$, míg vezetőtanárként is helytálló középiskolai tanárok körében $(\mathrm{N}=16) 13$ fö nevezte meg a szaktanári munkaközösséget mint összekötő kapcsot a kollégákkal. A szakértő tanárok, szaktanácsadók $(\mathrm{N}=26)$ körében 18-an jelölték meg e lehetőséget. Amennyiben a tanítókat, akik a „szaktanárok munkaközösségének” a szó szoros értelmében nem lehetnek tagjai, figyelmen kívül hagyjuk, és csupán azon kollégákat vesszük figyelembe, akik e területeken helytállnak, úgy az arány 70,2\%, ami valóban kiemelkedő.

Az azonos osztályokat tanítók csoportjának meghatározása szintén nehézségekbe ütközik, mivel több ilyen közösségnek tagja egy pedagógus, ugyanakkor - ahogy erre a későbbiek során visszatérünk - az egy osztályban tanítók közti együttműködés a kollektív hatékonyság biztosítása érdekében elengedhetetlen lenne. A tanítók közül $(\mathrm{N}=16) 4$ fó, a vezetőtanítók közül $(\mathrm{N}=4)$ további 1 személy, a felső tagozatos tanárok közül $(\mathrm{N}=15)$ 3, a középiskolai pedagógusok közül $(\mathrm{N}=27)$, a középiskolai vezetőpedagógusok $(\mathrm{N}=15)$ közül további 1 , valamint a szakértő vagy szaktanácsadó pedagógusok $(\mathrm{N}=26)$ közül 2 fó jelölte meg mint legföbb csoportösszetartó erőt. (Erre vonatkozóan lehetséges, hogy meg kellett volna kérdeznünk, hogy hány osztályban tanítanak, hiszen - feltevésünk szerint - minél több közösségnek tagja valaki, annál kisebb a jelentősége az odatartozásának.)

A szakvezetők csoportját összetartó erőként - érdekes módon - nem csupán szakvezetők jelölték meg. A tanítók közül $(\mathrm{N}=16) 2$ fö, a vezetőtanítók $(\mathrm{N}=4)$ közül egy személy, valamint a középiskolai vezetőtanárok közül $(\mathrm{N}=16) 6$, a szaktanácsadó, illetve szakértő tanárok körében $(\mathrm{N}=26)$ szintén 6 fö számára fontos. Viszonylag kiemelt szerepűnek 
tehát kizárólag a középiskolai vezetőtanárok számára tűnik, hiszen 37\%-ban körükben a legnépszerűbb e feladatkör mint csoportépítő tényező.

Az azonos épületet a tanítók esetében $(\mathrm{N}=16)$, a vezetőtanítók $(\mathrm{N}=4)$ körében 2 , a felső tagozaton tanító általános iskolai tanárok között $(\mathrm{N}=15) 7$, míg vezetőtanár társaik esetében $(\mathrm{N}=10)$ csupán 2, a középiskolai tanárok körében $(\mathrm{N}=27) 7$, a középiskolai vezetőtanárok $(\mathrm{N}=16)$ között 4 , a szakértők, szaktanácsadók esetében $(\mathrm{N}=26) 9$ fö tekinti lényeges összetartó erőnek. A tanítók és általános iskolai felső tagozaton tanítók tehát, akik lényegesnek ítélik e közösséget. Különösképpen igaz ez a tanítókra, akik az esetek több mint felében úgy nyilatkoztak, e tényező lényeges pedagógusi közösséghez tartozásuk szempontjából.

Az azonos képzési formában dolgozók csoportjának szerepét is vizsgáltuk, feltételezve, hogy a gyakorlóiskolai pedagógusok számára az, hogy ők tanítók, felső tagozatos tanárok vagy középiskolai tanárok, esetleg szakképzésben dolgoznak, lényeges szerepet játszik szakmai önmeghatározásuk szempontjából.

Az általános iskolai tanítók $(\mathrm{N}=16)$ körében 6 , míg vezetőtanítóként dolgozó társaik $(\mathrm{N}=4)$ közül további 2, a felső tagozaton tanító általános iskolai pedagógusok közül (N = 15) 5, vezetőtanár társaik közül $(\mathrm{N}=10) 3$, a középiskolai tanárok közül $(\mathrm{N}=27) 9$, a középiskolai vezetőtanárok körében $(\mathrm{N}=16) 7$, míg a szakvezetők esetében $(\mathrm{N}=26) 12$ fó gondolja úgy, hogy lényeges a szerepe e tényezőnek, mely 38\%-os megjelölési arányával nem tekinthető elhanyagolhatónak.

Mindent egybevetve gyakorlatilag az intézményben töltött évek számától, beosztástól, státusztól függetlenül a következőket jelenthetjük ki:

A három, ténylegesen a hatékony munkavégzést segítő tényező mellett (melyek között a szaktanári munkaközösség tekinthető vezető tényezőnek 55 fös megjelölési gyakoriságával, míg 38-as megjelölési gyakorisággal az azonos képzési forma és a személyes szimpátia áll 2-3. helyen), 4. (vagy inkább 3.) leglényegesebb a maga 36 megjelölési gyakoriságával az azonos épület.

Az azonos osztályokban tanítók közösségei, tehát a különböző tantárgyakat oktató, de egy-egy osztály vonatkozásában együttműködésre „kényszerülo”” csoportok között azonban igen laza a kapcsolat.

\subsubsection{A pedagógusok tantárgyi koncentrációhoz füződő viszonya}

Mint arra tanulmányunk bevezető részében utaltunk, a pedagógusi hatékonyságot több szerző kollektív hatékonyságként értelmezi. (E kérdéskörrel bővebben az 5. fejezetben foglalkozunk.) Magunk is ekként definiáltuk azt vizsgálatunk során. Ennek egy lényeges aspektusának a tantárgyi koncentrációt mint tudatos szakmai együttműködést tekintettük az egy osztályban tanítók esetében. E területre vonatkozó kérdésünk így hangzott: „Ön megvalósíthatónak tartja-e a tantárgyi koncentráció érdekében történő együttműködést a kollégákkal?” E kérdésre, igen 
érdekes módon 100\%-ban, egybehangzó „igen” volt a felelet, 95 fó válasza alapján. Terveztük, hogy vizsgáljuk e tendenciát a pedagógusok által betöltött pozíció függvényében is, ám így okafogyottá vált, mivel valamennyi képzési területen úgy vélték a megkérdezett kollégák, hogy a tantárgyi koncentráció megvalósítható, legalábbis 83 válaszadó felelt így, 12-en nem adtak választ. Vélhetően közöttük lehettek akár egyet nem értők is. Ez a nyilvánvaló „egyetértés” azonban némiképp megkérdőjeleződik a következő válaszadásukban.

Az együttműködés legjellegzetesebb formájának a közös projektek szervezése tűnik. (67 említést kapott a 183 válaszadásból.) Ez az adat azonban ennél is nagyobb jelentőségü, hiszen 54-en felelték azt, hogy az előző kérdésre - mely arra vonatkozott, hogy megvalósíthatónak látják-e kollégáikkal a tantárgyi koncentráció formájában történő együttműködést - nemmel válaszoltak, azonban csupán 12 fö nem felelt az előző kérdésre, ugyanakkor senki nem állította, hogy ne törekedne az együttműködésre. Csupán 6 esetben kaptuk azt a választ, hogy törekszenek rá, míg másokban nincs erre igény. A projektek mellett még a tanácskérés mint az együttmüködés formája, illetve az a kijelentés fordult elö, miszerint természetesnek vélik a pedagógusok a tantárgyi koncentrációt. A vonatkozó hipotézisünk megdőlt, miszerint jellemzően „másokra mutogatnának” a pedagógusok a tantárgyi koncentrációt célzó feladatok meghiúsulása miatt. (Az együttműködés egyéb formáiról szintén a légkört bemutató 5 . fejezetben írunk.)

\subsection{A szülők és a gyakorlóiskola pedagógusai}

A szülőknek a gyakorlóiskola életébe való bevonódással kapcsolatos nézeteinek vizsgálata, illetve annak pedagógusok vonatkozó nézeteivel való összevetése során azt találtuk, hogy közepes mértékben érzik a szülők a pedagógus-szülő kommunikációt hatékonynak, nem tekintik egyértelmüen barátinak a kapcsolatot, ugyanakkor úgy vélik, általában képesek beszélgetni a pedagógusokkal kötetlenül is. Elismerik, hogy az iskolát érintő lényeges kérdésekben általában velük is konzultálnak a pedagógusok, ugyanakkor ambivalensnek tekinthető bevonódottságérzetük. Az azonban semmiképp nem tekinthető a pedagógusok elutasítása jelének, hogy egymással szívesebben konzultálnak a szülők. Ez feltételezhet erős szülői munkaközösséget is (lásd melléklet, 4. táblázat).

\subsubsection{A szülők és a pedagógusok}

A szülők és pedagógusok kapcsolatának átfogó vizsgálata során rákérdeztünk, mely esetekben keresik fel őket a pedagógusok általánosságban, illetve az osztályfőnök. 


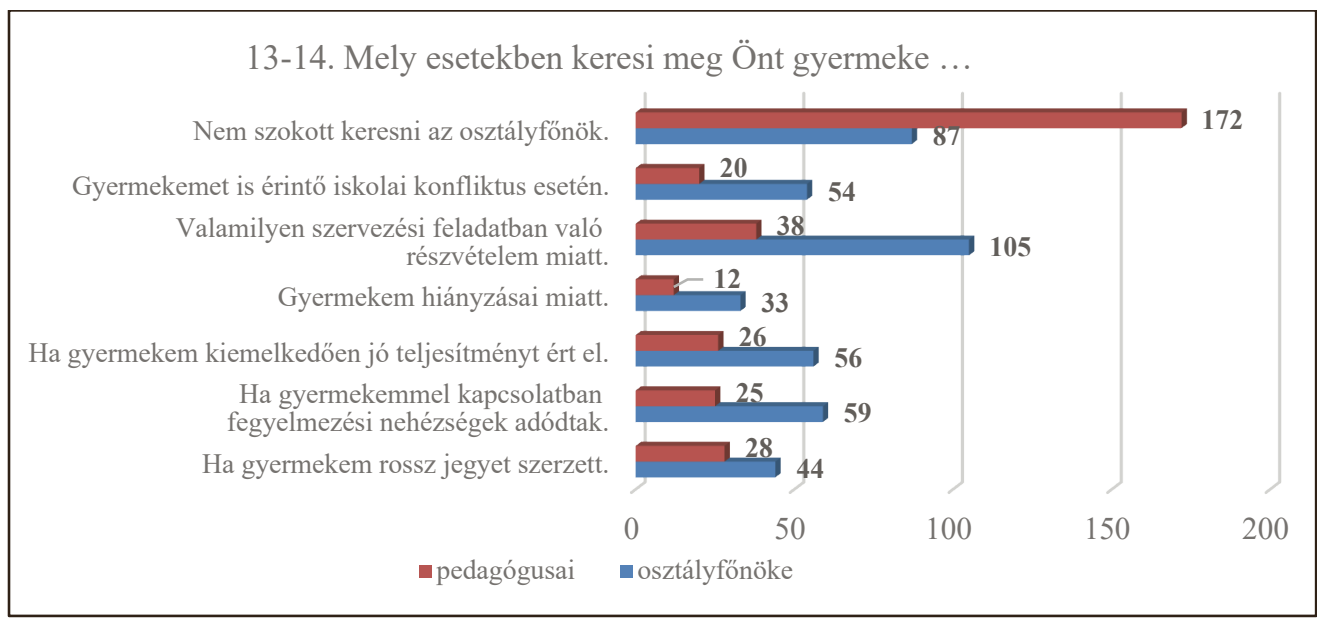

4.2. ábra: Pedagógusok és osztályfőnökök szülőket érintő megkeresésének okai

Ahogy azt a 2. ábra is mutatja, jellemzően, ha az osztályfőnök nem keresi a szülőket, más pedagógusok sem szokták.

\begin{tabular}{|l|c|c|c|c|}
\hline $\begin{array}{l}\text { 13-14. Mely esetekben keresi(k) } \\
\text { meg Önt gyermeke }\end{array}$ & $\begin{array}{l}\text { osztály- } \\
\text { fönöke }\end{array}$ & Rangsor & $\begin{array}{l}\text { pedagó- } \\
\text { gusai }\end{array}$ & Rangsor \\
\hline $\begin{array}{l}\text { Ha gyermekem rossz jegyet } \\
\text { szerzett. }\end{array}$ & 44 & 6. & 28 & 3. \\
\hline $\begin{array}{l}\text { Ha gyermekemmel kapcsolat- } \\
\text { ban fegyelmezési nehézségek } \\
\text { adódtak. }\end{array}$ & 59 & 3. & 25 & 5. \\
\hline $\begin{array}{l}\text { Ha gyermekem kiemelkedően jó } \\
\text { teljesítményt ért el. }\end{array}$ & 56 & 4. & 26 & 4. \\
\hline Gyermekem hiányzásai miatt. & 33 & 7. & 12 & 7. \\
\hline $\begin{array}{l}\text { Valamilyen szervezési feladat- } \\
\text { ban való részvételem miatt. }\end{array}$ & 105 & 1. & 38 & 2. \\
\hline $\begin{array}{l}\text { Gyermekemet is érintó iskolai } \\
\text { konfliktus esetén. }\end{array}$ & 54 & 5. & 20 & 6. \\
\hline $\begin{array}{l}\text { Nem szokott keresni (az } \\
\text { osztályfönök/pedagógus). }\end{array}$ & 87 & 2. & 172 & 1. \\
\hline Összesen & $\mathbf{4 3 8}$ & & 321 & \\
\hline
\end{tabular}

4.1. táblázat: Pedagógusok és osztályfőnökök szülőket érintő megkeresésének okai - rangsorolva (saját szerk.) 
A legjellegzetesebb tendencia a nem osztályfönök beosztású pedagógusok körében, hogy nem keresik a szülőket, ugyanakkor azt le kell szögeznünk, hogy amennyiben mégis, úgy elsősorban szervezési feladatok megvalósulásában való közreműködésük okán teszik ezt. Az ezt követő leggyakoribb tényező pedagógusok esetében a rossz érdemjegy, melytől nem marad el jelentős mértékben a kiemelkedő teljesítmény, illetve a fegyelmezési nehézségek. A közöttük lévő sorrend nagyobb szülői minta esetén akár még módosulhatott volna, így gyakorlatilag állíthatjuk, hogy e tényezők igen hasonló fontosságú alapjai a pedagógus-szülő kommunikációnak. Nem jellemző, hogy konfliktusok, illetve hiányzások miatt keresnék a pedagógusok a szülőket (1. táblázat).

A rangsorban a hiányzások az osztályfönöki megkeresések lehetséges indítékaként is utolsó helyen állnak. Bár pedagógusokra kevésbé jellemző, hogy rossz jegy miatt felkeresnék a szülőket, mint az osztályfönökökre, a rangsorban mégis előrébb került, hiszen ha keresik a szülőket, annak jellemzően nyomós oka van. Feltételezhetjük, hogy saját tantárgyuk érdemjegyeit igyekeznek ők megosztani a szülőkkel, bár kérdőívünk eredményeiből egyértelmüen nem derült ki, hogy mit jelent a rossz jegyek, fegyelmezési nehézségek, jó teljesítmény okán történő megkeresés: felhívják a szülőket vagy esetleg csupán annyit tesz, hogy a tájékoztató füzetbe beírják az érdemjegyeket vagy egy-egy szaktanári figyelmeztetést.

Osztályfönökök esetében jellemző, hogy a szervezésben történő részvétel mellett jellemzően fegyelmezési problémák, kiemelkedő teljesítmény, illetve konfliktushelyzet esetén keresik fel igen hasonló gyakorisággal a szülőket. A rossz jegy mint indíték esetükben kevéssé kerül előtérbe, talán mert nem ezt tekintik a szülők az osztályfönöki megkeresés fő okának. Azt sem tudjuk, hogy az osztályfőnök más pedagógusoknál szerzett vagy saját tantárgyából adott jegyek miatt keresi-e fel a szülőket. Ha e területekre vonatkozóan további kutatást folytatnánk, vélhetően átfogóbb képet kaphatnánk a pedagógus-szülő kommunikáció jellegzetességeiről. Következő táblázatunk azonban némiképp hiánypótlónak tekinthető, hiszen rámutat arra, melyek azok a helyzetek, melyek esetén mind a szülő, mind az egyéb pedagógusok megkeresik a szülőket (lásd 5. táblázat).

E feleletek alátámasztani látszanak azon feltevésünket, miszerint a szülők többé-kevésbé részesei az iskola életének, és bevonják őket a pedagógusok az intézményt érintő lényegesebb eseményekbe. (Az iskola színvonalát bemutató 6. fejezetben ugyanerre világítunk rá, a pedagógusok szemszögéből szemléltetjük továbbá a 6.13. táblázatban, melyben látható, hogy a gyermek után a szülők visszajelzései leginkább fontosak számukra.)

Vélhetően ez alatt érthetik a szervezési feladatokat is, mely által az iskola arculatának formálásában is aktívan részt vesznek, így téve vonzóvá az iskolát. Fegyelmezési gondok esetén 25 szülö állítja, hogy a pedagógusok megkeresik. Közülük 22-en ugyanebben a helyzetben azt válaszolják, az osztályfönök is jelentkezik. Kiemelkedő tanulmányi teljesítmény esetén szintén 22 szülő véli úgy (a 26 pedagógusokra vonatkozó megjelölésből), hogy mind 
a pedagógusok, mind az osztályfönökök megkeresik. Konfliktus esetén 20 szülő válaszolta, hogy a pedagógusok megkeresik, ebből 16-an vélik úgy, hogy az osztályfönök is. Szervezési feladatok vonatkozásában a szülők úgy gondolják, nem fordul olyan elö, hogy csak valamely szaktanár keresse őket, hanem az osztályfönök is. Ez mind a 38 vonatkozó jelölésre igaz.

Levonhatjuk a következtetést: egyértelmű, hogy a szervezéssel, tanulói teljesítménnyel, illetve fegyelmezéssel kapcsolatos helyzetek a legjellegzetesebb okai a megkeresésnek, ám a legfőbb „összekötő” a pedagógusok és a szülők között az osztályfönök, ugyanakkor mivel az egy osztályban tanítók közti összetartás érzése nem tekinthető szorosnak (ahogy arra korábban rámutattunk), így e tényező sem jelent feltétlen megoldást a hatékony tanár-szülő kommunikáció fejlesztésére.

\subsubsection{A pedagógus-szülö kommunikáció fő csatornái}

A fentieket továbbgondolva alkottuk meg H3.1 alhipotézisünket - feltételezve, hogy a tanár-szülő kapcsolat egyelőre még inkább hivatalos jellegü, semmint baráti -, érdekelt minket, vajon ezt tükrözi-e mindennapi kommunikációjuk is. Eredményeinket a következő grafikon segítségével szemléltetjük:

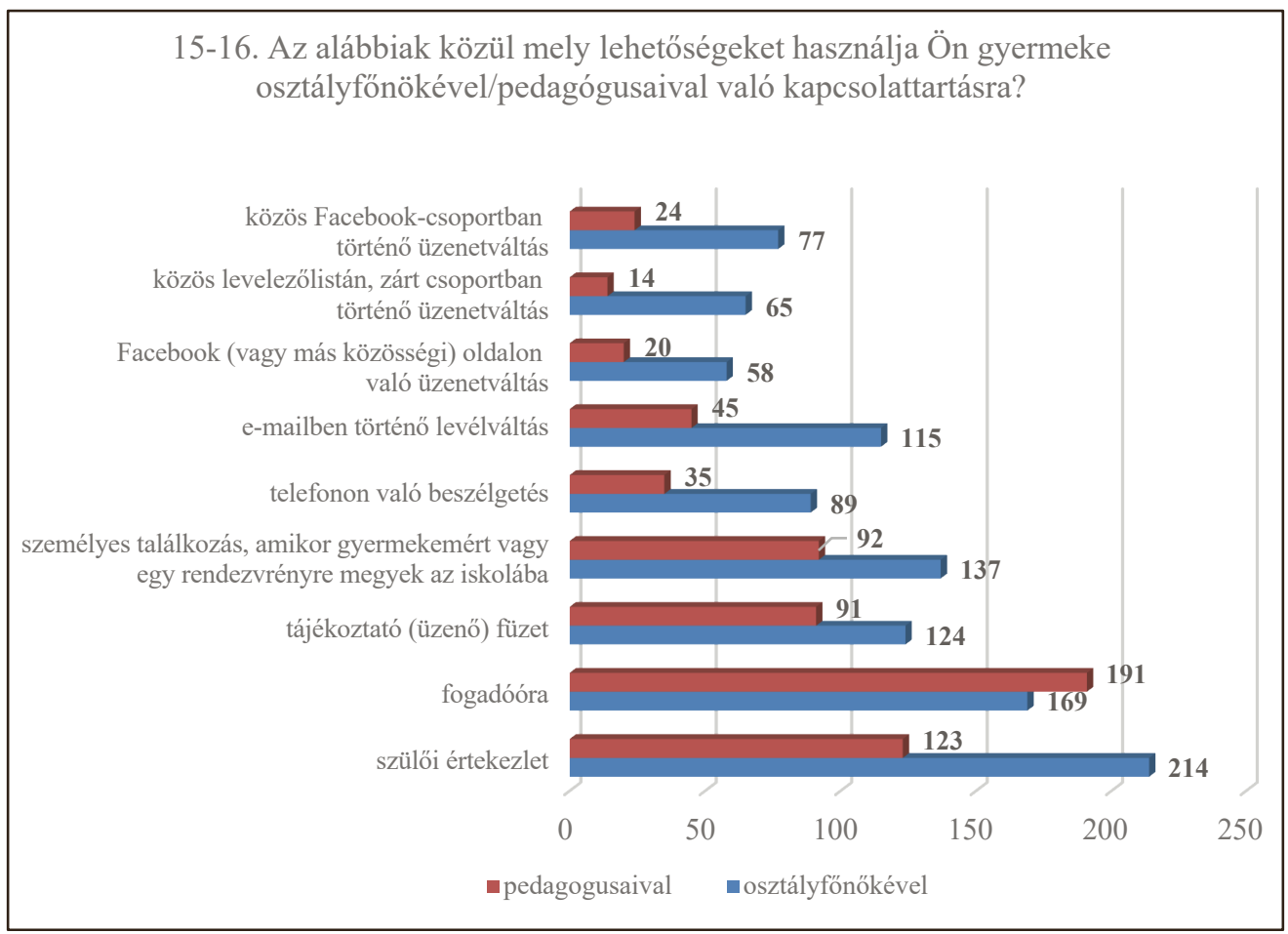

\section{3. ábra: A pedagógusokkal való érintkezés kommunikációs csatornáinak jelölési gyakorisága szülők körében (saját szerk.)}


Ezen adatok arról árulkodnak (3. ábra), hogy az osztályfőnök az, aki a legintenzívebben, a legtöbb csatornán tart kapcsolatot a szülőkkel, más pedagógusok kevésbé. (Ezen eredmények alapján a korábban kevésbé differenciált kérdéseket is fel lehetne tenni a szülőknek mind a nem osztályfönökként dolgozó, mind az osztályfőnökként dolgozó pedagógusok vonatkozásában, hogy átlássuk, kik azok, akikkel baráti a kapcsolat, kikkel beszélgethetnek kötetlenül a szülők, és kik azok, akikkel gyakorlatilag alig van kommunikáció. E vizsgálat tapasztalatai alapján csupán megalapozott feltételezésekbe bocsátkozhatunk, miszerint az egyes osztályfönökök igen gyenge láncszemek az általános pedagógus-szülö kommunikációban, mivel az egy osztályban tanítók között szint szoros kapocs. Ugyanakkor azt a következtetést is levonhatjuk, hogy nem kizárólag az osztályfönök összekötő szerepére számítanak a szülők, hiszen többen egy-egy rendezvény alkalmával is beszélgetnek gyermeküket nem osztályfönökként tanító pedagógusokkal. Természetesen további vizsgálatok lehetnek szükségesek ahhoz, hogy megállapítsuk, általános érvényü-e ez a jelenség, vagy csupán az adott intézmény esetében, az adott időszakra vonatkoztatható.)

A fogadóóra az, ahol leginkább módja van a szülőknek az egyes pedagógusokkal való találkozásra. Szülői értekezleten többnyire csak az osztályfőnök van jelen. A tájékoztató füzet és az iskolában rendezvényen vagy a gyermekért menéskor történő spontán találkozás szintén népszerű kommunikációs forma volt vizsgálatunk idején, ugyanakkor ennek helyét egyre inkább a digitális napló veszi át napjainkban, így ezen eredményünk szintén aktualizálást igényel. Ekkoriban megállapítottuk, hogy természetes, hogy az osztályfönökökkel ezek hatékonyabban müködnek, míg a fogadóóra elsődleges célja, hogy a szaktanárokkal beszéljenek a szülők (szervezési feladatokról is akár, de főképp a gyermek tanulmányi eredményeiről). A személyesebb kommunikációs formákat, az internet adta lehetőségeket azonban elsősorban az osztályfőnökök esetében használják a szülők, illetve az osztályfőnökök élnek ezekkel a szülőkkel való kapcsolattartás során.

Azt is vizsgáltuk, melyek azon kommunikációs eszközök, amelyeket a szülők egyaránt bejelöltek a pedagógusok, illetve az osztályfonnökök vonatkozásában. (Melléklet 6. táblázat) 119 szülö mind az osztályfönökkel, mind a pedagógusokkal való kapcsolattartásra a szülői értekezletet tekintete leginkább alkalmasnak. Ezt különösnek találtuk, ugyanis a szülői értekezlet célja elsősorban az osztályfőnökkel folytatott megbeszélés. Ennél is figyelemreméltóbb azonban, hogy 171 olyan szülő akadt, aki úgy nyilatkozott, fogadóórán a pedagógusokkal, szülői értekezleten az osztályfönökkel beszél, míg ennél alig kevesebben, 159-en mind az osztályfönökkel, mind a többi pedagógussal a fogadóórán beszélgetnek szívesebben. 88-an érezték úgy, hogy mindkét irányban lényeges tényező a spontán személyes találkozás. Feltételezhető, hogy többen alakítottak ki közös Facebook-csoportot, illetve egyéb közös levelezőlistát a pedagógusok és szülők számára, mivel 21-en nyilatkoztak úgy, hogy élnek mindkét irányban ezen lehetőséggel, ugyanakkor mivel 247 szülőt kérdeztünk 
meg, valószínűsítettük, hogy egy-egy osztályból csupán egy-két szülő (pl. szülői munkaközösség-vezető) lehetett aktív e csoportokban.

247 válaszadó szülő közül tehát 29 nem kommunikál szülői értekezleten sem az osztályfőnökkel, sem egyéb pedagógusokkal, 45 fö nem veszi igénybe a fogadóórán egyik féllel való kommunikáció lehetőségét sem. 116-an nem a tájékoztató/üzenőfüzet útján érintkeznek az osztályfőnökkel, illetve pedagógusokkal, 106-an nem tekintik ideális lehetőségnek a beszélgetésre azt, amikor gyermekükért vagy egy rendezvényre érkeznek az iskolába. 145 fő nem beszél semelyik pedagógussal telefonon, az elektronikus kommunikáció eszközeit szintén elutasítja a többség. Talán az e-mail, mely hivatalosabb, mint egy közösségi oldalon történő kommunikáció, kevésbé népszerűtlen, hiszen azt „csupán” 130 -an nem jelölték, azaz 15 fóvel kevesebben, mint a telefont. Természetesen a szülői értekezlet és fogadóóra kivételével a kommunikáció hiányossága mindkét felet (pedagógusokat és szülőket is) terheli, hiszen annak elmaradásáért nem okolható csupán az egyik fél.

\subsection{A tanárjelöltek bevonódása az iskolaszervezet mindennapjaiba}

Bár a vizsgálatunkban részt vett pedagógusok alapvetően az iskolaközösség tagjai közé sorolták a pedagógusok és tanulók, szülők és oktatók mellett a tanárjelölteket is, utóbbiak úgy érezték, közösségben való részvételük kívánnivalót hagy maga után. (Azt is vallották, fontos számukra a visszajelzésük, lásd 6. fejezet 6.13 táblázat.)

Bár az átlageredmény - igen csekély elemszámú mintáról lévén szó - nem tekinthető mérvadónak, és az az által kialakított rangsor sem, az mindenesetre szembetűnő, hogy kevés aspektusát láthatták az intézménynek a hallgatók, hiszen nem vehettek részt értekezleteken, ugyanakkor jellemzően láthatták több iskolatípus (pl. felső tagozat és középiskola) működését, azonban sem 12., sem 13. évfolyamon nem nyílt lehetőségük tanórákat tartani. Figyelemre méltó azonban, hogy általános iskola felső tagozatán és középiskolában egyaránt volt módjuk szerepelni gyakorlataik során.

Elsősorban tanórákat hospitáltak és tartottak, emellett többen részt vehettek szakkörök megtartásában, megjelenhettek szabadidős programokon, láthattak tehetségfejlesztést, felzárkóztatást, ugyanakkor csekély mértékben érezték magukat a szervezet részének, és nem gondolják, hogy képet kaphattak volna a nevelőtestület működéséről. Nevelőtestületi értekezleten is csupán 2 fó vehetett részt. Az iskola életébe való bevonódás hiányosságaira utal, hogy az intézmény hagyományápoló tevékenységébe 9 hallgató nem kapcsolódott be, 2 inkább nem jellemző, hogy részt vett volna. 


\begin{tabular}{|c|c|c|c|c|c|c|c|}
\hline $\mathrm{N}=\mathbf{2 2}$ & 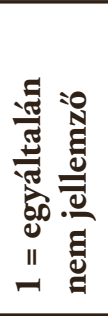 & 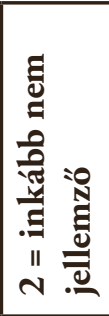 & 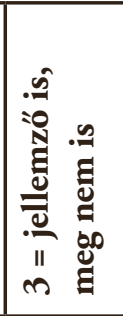 & 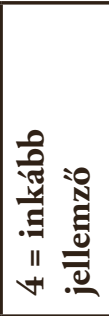 & 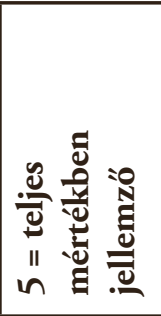 & 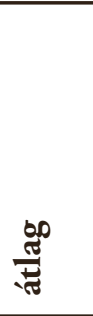 & 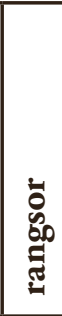 \\
\hline $\begin{array}{l}\text { Lehetőségem nyílt } \\
\text { a gyermekvédelmi } \\
\text { felelős munkájába } \\
\text { bepillantani. }\end{array}$ & 10 & 6 & 4 & 0 & 2 & 2 & 3 \\
\hline $\begin{array}{l}\text { Lehetőségem volt } \\
\text { a gyógypedagógus } \\
\text { munkájába } \\
\text { bepillantani. }\end{array}$ & 11 & 4 & 4 & 0 & 3 & 2,63 & 2. \\
\hline $\begin{array}{l}\text { Fejlődtem a szülőkkel } \\
\text { való együttmúlködés } \\
\text { terén. }\end{array}$ & 16 & 5 & 1 & 0 & 0 & 1,31 & 4. \\
\hline $\begin{array}{l}\text { Fejlődtem } \\
\text { a gyakorlóiskolában } \\
\text { dolgozó kollégákkal } \\
\text { való együittmúkiödés } \\
\text { terén. }\end{array}$ & 6 & 4 & 3 & 5 & 4 & 2,86 & 1. \\
\hline
\end{tabular}

\section{2. táblázat: Az iskolaközösség életébe történő bevonás hiányosságai} (saját szerk.)

Az intézmény életébe való betekintési lehetőségüket jellemzi, hogy a hiányterületi tevékenységeket csekély mértékben volt módjuk megfigyelni. A szülőkkel - mivel csak keveseknek volt lehetőségük kommunikálni velük - nem jellemző, hogy fejlődött volna a hallgatók együttműködése. Leginkább - bár kiemelkedőnek korántsem tekinthető mértékben a gyakorlóiskolában dolgozó kollégákkal való együttműködése fejlődött a tanárjelölteknek.

Iskolai ünnepségeken, megemlékezéseken 12 fö vett részt, valamint egy fö jelezte, hogy ő diákönkormányzati ülésen is jelen volt. 6 fö vett részt karácsonyi, illetve farsangi rendezvényen. (Melléklet: 7. táblázat)

Alapjában véve azt mondhatjuk, hogy a tanárjelölteket elsődlegesen a tanórák megtervezésébe, az oktatási tevékenységük fejlesztésébe vonta be a testület, a tanári pálya szakmai oldalára lelkiismeretes és alapos felkészítést kaptak. 


\subsubsection{A tanárjelöltek és az autonómia}

Bár nem érezték a hallgatók egyértelműen, hogy a közösség - átmenetileg - befogadta őket, az viszont valószínűsíthető, hogy bizalmat szavaztak nekik, bizonyos fokú szakmai autonómiát élvezhettek.

\begin{tabular}{|c|c|c|c|c|c|c|}
\hline $\mathrm{N}=22$ & 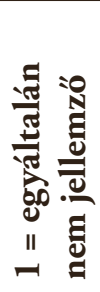 & 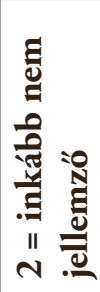 & 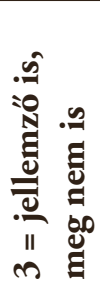 & 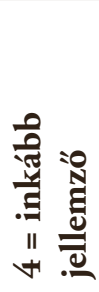 & 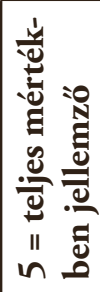 & $\frac{60}{\tilde{z}}$ \\
\hline $\begin{array}{l}\text { Megvalósíthattam } \\
\text { saját nevelési-okta- } \\
\text { tási ötleteimet. }\end{array}$ & 2 & 1 & 5 & 6 & 8 & 3,772 \\
\hline $\begin{array}{l}\text { Önállóan oldhattam } \\
\text { meg pedagógiai } \\
\text { feladatokat. }\end{array}$ & 1 & 2 & 4 & 6 & 9 & 3,909 \\
\hline
\end{tabular}

4.3. táblázat: A tanárjelöltek és a szakmai autonómia (saját szerk.)

A tanárjelöltek szakmailag fejlődtek, önállóbbakká válhattak, saját oktatási-nevelési ötleteik megvalósításában szabad kezet kaptak.

\subsubsection{A tanárjelöltek kapcsolatának alakulása a tanárokkal, tanulókkal}

A címben szereplő terület vizsgálata céljából megkérdeztük a tanárjelöltektől, hogy mely színtereken és társaságban töltik jellemzően óraközi szüneteiket: azt találtuk, hogy a hallgatók közül 14 fó (9 inkább, 5 fó teljes mértékben) jellemzőnek vallja, hogy a szüneteket a tanteremben tölti a tanulókkal, 9 fó esetében ( 5 fö esetén inkább, 4 személy szerint teljes mértékben) jellemző, hogy a folyosón beszélgetnek a diákokkal. A hallgatók eszerint tehát igyekeztek a tanulókkal kapcsolatot építeni. Ugyanakkor megállapíthatjuk, hogy nem a tanulókkal való beszélgetés volt az elsődleges időtöltési lehetőség a hallgatók körében, hanem sokkal inkább a vezetőtanárral, illetve a hallgatótársakkal való eszmecsere.

Eredményeinkből kitűnik, hogy bár leginkább a folyosón vagy a tanteremben vannak a tanárjelöltek, a tanári is - a vezetőtanár jelenlétében - megfelelő helyszínnek tűnik.

(Az iskola színvonalát bemutató 6. fejezetben - 6.28. táblázat-részletesen bemutatjuk e kérdés pedagógusi aspektusát. A pedagógusok is alátámasztják a tanárjelöltek állítását, miszerint jellemzően a tanáriban vagy a tanteremben zajlanak a megbeszélések, ennél kevésbé jellemző, 
hogy a megbeszélőszobában. Ennek oka, hogy egyszerre több tanárjelölt is lehet az iskolában, és e szoba kicsi. Ilyenkor szorulhatnak ki jellemzően a folyosóra, vagy dönthetnek úgy, hogy a tanáriban folytatják le az eszmecserét, esetleg maradnak a tanteremben.)

\section{Hipotéziseink igazolása}

Jelen tanulmányunk 4. részében ismertetett eredményeink tükrében induló hipotéziseink a következőképpen alakultak:

H1: A gyakorlóiskola közössége alapvetöen iskolaközösségként definiálja magát.

A gyakorlóiskola pedagógusközössége valóban iskolaközösségként definiálta magát. H1.1: A pedagógusok a szülöket, pedagógusokat, diákokat az iskolaközösség részének tekintik, nem állitják azonban ugyanezt az egyetemi oktatókról és a tanárjelöltekröl.

A gyakorlóiskola pedagógusai elsősorban olyan iskolaközösséggel kapcsolatban gondolkodtak, melynek diákok, szülolk, hallgatók, oktatók részei. Azon feltevésünk tehát, miszerint a hallgatókat és oktatókat ne tekintenék a pedagógusok a közösség „szerves”, egyenrangú részének, megdőlni látszik.

H1.1.1: A szülökkel kapcsolatban a tanárok úgy nyilatkoznak, hogy részei a közösségnek, ugyanakkor a szülök szerint a kapcsolattartás az osztályfönökökre korlátozódik.

Igazolódott, hogy a szülőkkel kapcsolatban a tanárok úgy nyilatkoznak, hogy részei a közösségnek, ugyanakkor a szülők valóban nem érzik magukat az iskolaközösség „szerves részének". Az osztályfőnökök elsődlegesen azok, akik bekapcsolják őket az intézmény életébe. H1.2: A tantárgyi koncentráció megvalósitására törekvés nem jellemzö a pedagógusokra.

Ezen alhipotézisünk megdőlt, hiszen a tantárgyi koncentráció megvalósítására alapvetően törekszenek a gyakorlóiskola pedagógusai. Jellemző a közös projektek szervezése. H2: A szülök bevonódottságérzete ambivalens.

A szülők bevonódottságérzete valóban ambivalens, de inkább kedvezőnek mondható. A válaszadó szülők körülbelül fele vallotta, hogy részese az intézmény mindennapjainak, barátinak tekinthető a kapcsolat a szülők és pedagógusok között, és akkor is lehet beszélgetni a tanárokkal, ha „minden rendben van”.

H2.1: A szülök a „hagyományos" pedagógus-szülo" kapcsolat hivei, és csupán a szükséges kommunikációra szoritkoznak.

A szülők valóban elsősorban a szülői értekezleteket, fogadóórákat tekintik legideálisabbnak a pedagógusokkal való kommunikációra, ugyanakkor jellemző, hogy spontán módon, egy-egy rendezvényen is szívesen beszélgetnek a tanárokkal.

H2.2: Elképzelhetö, hogy Facebook- vagy egyéb közösségi csoportokat alakitanak ki pedagógusok és szülök, ám ezek csekély mértékben népszerüek. 
Az internetes kommunikációs lehetőségek valóban háttérbe szorultak ekkor (még) a személyes, hagyományos megkeresési módokkal szemben, azonban már ekkor sem határolódtak el az előbbiektől a szülők, ugyanis többen jelezték, hogy mind szaktanárokkal, mind pedagógusokkal e felületeken kommunikálnak.

H2.3: Az osztályfönök jellemzöen egyfajta ellenöri szerepben van jelen. (Pl. fegyelmezési problémák esetén keresi a szülöket.)

E hipotézisünk megdőlt, hiszen vizsgálati eredményeink arról árulkodtak, hogy az osztályfönök elsősorban nem fegyelmezési vagy egyéb, kellemetlen okokból keresi a szülőt, hanem a megkeresés elsődleges oka, ha valamely szervezési feladatban számít a szülő együttműködésére. H2.4: Az osztályfönök az, aki szoros kapcsolatot ápol a szülökkel, míg a többi pedagógusra ez kevésbé jellemzö.

Elsősorban valóban az osztályfőnök az, aki kapcsolatot tart fenn a szülőkkel, ugyanakkor a szülők más pedagógusokkal is kommunikálnak szervezési feladatok, kiemelkedő tanulmányi eredmények, fegyelmezési problémák esetén, illetve jellemzően fogadóórán és szülői értekezleten beszélgetnek e tanárokkal.

H3: A tanárjelöltek iskolaközösséggel kapcsolatos bevonódottságérzete csupán némely dimenzió mentén fejlödött.

Jelen hipotézisünk igazolást nyert, hiszen a hallgatói beszámolókból egyöntetűen a „kívülállóság” érzete tűnik ki. Jelen megállapításunkat a következő alhipotézisek igazolásában vázoljuk:

H3.1: A tanárjelöltek jellemzöen csupán tanórákat hospitálhattak és tarthattak, ugyanakkor a szervezet életébe csekély mértékben tudtak bevonódni (nem vehettek részt értekezleteken, nem kapcsolódtak be másik iskolaszint munkájába).

A nevelőtestületi értekezleteken való részvétel, valamint a hagyományápoló tevékenységekbe történő bevonás, hiányterületi pedagógusok munkájába való bepillantás, illetve - ahogy arra a következőkben kitérünk - a szülőkkel való kapcsolattartás csekély szerepet játszott a tanárjelöltek gyakorlata során, hiszen sem a gyógypedagógus, sem a gyermekvédelmi felelős munkáját nem állt módjukban a válaszadó tanárjelölteknek megismerni, továbbá nem jellemző, hogy hagyományápoló tevékenységeken, valamint szülői értekezleteken, fogadóórákon jelen lettek és azokon aktívan részt vehettek volna.

H3.2: A tanárjelöltek és a szülök közt nem fejlödött a kapcsolat.

A szülőkkel való együttműködés terén valóban nem fejlődtek a tanárjelöltek. Ezt támasztja alá, hogy erre lehetőséget adó alkalmakon (szülői értekezlet, fogadóóra) nem vehettek részt, illetve a tanárjelöltek azon nézetei, mely szerint nem fejlődtek a szülőkkel való kapcsolattartás vonatkozásában.

H.3.3: A hallgatók elsösorban a vezetötanárral, illetve a tanulókkal épitették kapcsolatukat, a nevelötestület többi tagjával erre kevesebb lehetöségük volt. 
A hallgatók elsősorban a vezetőtanárral, a tanulókkal, illetve hallgatótársaikkal beszélgettek gyakorlataik idején az óraközi szünetekben, míg a nevelőtestület tagjaival gyakorlatilag egyáltalán nem kommunikáltak.

H3.4: Az egyetemi oktatók a tanárjelöltekkel tartották a kapcsolatot a gyakorlóiskolai tanitási gyakorlataik ideje alatt.

A hallgatói beszámolókból kitűnik, hogy valóban tartották a kapcsolatot a tanárjelöltek oktatóikkal, bár nem tekinthető teljes mértékben jellemzőnek.

\section{Javaslatok}

Kutatásunk összegzésekor néhány - napjainkban is mérlegelhetö/mérlegelendő - javaslatot fogalmaztunk meg:

1. A tanárjelöltek gyakorlatai vonatkozásában esetleg megfontolásra érdemes, hogy több belelátást nyerhetnének az iskola életében szerepet játszó foglalkozásokba, rendezvényekbe. A következő lehetőségekkel élhetnének a pedagógusok:

1.1. A tanárjelöltek bevonása felzárkóztató, tehetségfejlesztő foglalkozásokba, szabadidős programokba, csoportépítést segítő elfoglaltságokba. Amennyiben megvalósítható, érdemes lenne bevonni őket egy-egy értekezlet, fogadóóra lebonyolításába, esetleg online csoportokban is kommunikálhatnának szülőkkel.

1.2. A pedagógusok és tanárjelöltek kapcsolatának erősítése érdekében be lehetne vonni hallgatókat közös, iskolai, illetve iskolán kívüli projektekbe, együttműködhetnének a diákönkormányzatot segítő pedagógussal, támogathatnák a gyakorlóiskola arculatának fejlesztését diákokkal közösen írt kisebb online cikkek, blogok által, népszerüsítve ezzel a gyakorlóiskola és az egyetem munkáját, együttműködését is, és közelebb hozva azt fiatalokhoz, későbbi lehetséges tanárjelöltekhez. Az osztályfőnöki órákon beszélgethetnének ezekről, építhetnék a közösséget, hiszen jelenleg sok esetben e foglalkozásokat csupán „letanított óraként” élhetik meg a tanárjelöltek.

1.3. Az online felületek szerepét a tanárjelöltek és tanulók, valamint az általában vett iskolahasználók körében célszerü lenne kiaknázni, hiszen a nappali tagozatos hallgatók és a tanulók számára is kedvelt kommunikációs felületek ezek.

1.4.Érdekes elképzelés lehet, hogy a félév/tanév kezdetén, mikor a tanárjelölt megtudja, mely osztályoknál lesz gyakorlaton, előzetesen interneten megismerkedne az osztály zárt csoportjával (legtöbb iskolában, így vélhetően a gyakorlóiskolában is vannak ilyenek), melyet szabadidős programok követnének, és csak ezt követően kerülne sor a tanórák megtartására. 
1.5. Érdemes lehet közös szabadidős programokat, játékokat szervezni az iskola több szereplője - tanárok, diák, tanárjelöltek, szülők - számára, mely fakultatív, mégis közösségépítő jellegű lenne. Elengedhetetlen lenne olyan programok megvalósítása, melyben a tanárjelöltek is a közösség tagjának érezhetnék magukat, és nem csupán a vezetőtanár „feladatának”.

Az 1.1., 1.2. és 1.4. számú javaslatnak a járványveszély ideje alatt is pályaszocializációt támogató szerepe lehet. Egy szakmai fejlesztő iskola koncepciójának kialakítása során tehát érdemes lehet arra is odafigyelni, hogy ilyesfajta online interakciókban helyt kapnak-e a pedagógusjelöltek.

\section{Felhasznált irodalom:}

Bandura, A. (1977): Self-efficacy: Toward a unifying theory of behavioral change. In: Psychological Review, 84, pp. 191-215. https://doi.org/10.1037/0033-295X.84.2.191 Bandura, A. (2001): Social cognitive theory: An agentic perspective. Annual Review of Psychology, 52, 1-26. https://doi.org/10.1146/annurev.psych.52.1.1

Bruner, J. S. (1973): The Relevance of Education. In Actual Minds, Possible Words, Norton, New York, Harward University Press.

Caprara, G. V., Barbaranelli, C. Steca, P. \& Malone, P. S. (2006): Teachers' self-efficacy beliefs as determinants of job satisfaction and students' academic achievement: A study at the school level. Journal of School Psychology, 44. 473-490. Elérhető: https://www. sciencedirect.com/science/article/pii/S0022440506000847 Letöltés: 2021. január 1. https://doi.org/10.1016/j.jpp.2006.09.001

Csapó, J. és Csécsei, B. (2011): Az iskola szervezeti kultúrája, Szegedi Tudományegyetem Közoktatási Vezetőképző Intézet.

Falus, I. (2001): Pedagógus mesterség - pedagógiai tudás. In: Iskolakultúra.2001/ 2. sz. $21-28$.

Falus, I. (2002): A tanuló tanár. Iskolakultúra, 2002/6-7, 76-80.

Falus, I. (2004): A pedagógussá válás folyamata. In: Pedagógusképzés. 2004/3. 359-374.

F. Lassú, Zs. - Podráczky, J.- Glauber, A. - Perlusz, A. - Marton, E. (2012): Nemzetközi kutatások a szülői részvétel hatásáról. In: Szövetségben - Tanulmányok a család és az intézményes nevelés kapcsolatáról. ELTE Eötvös Kiadó, Budapest. (13-41.)

Fűzi, B. (2007): A sikeres pedagógiai munka néhány összetevője. Egy kísérlet tanulságai. In: Pedagógusképzés 2007/3. 9-30. 
Fűzi, B. (2012): A tanári munka sikeressége a pedagógiai attitűdök, a tanár-diák viszony és az iskolai élmények összefüggésrendszerében. PhD-dolgozat (kézirat), Budapest.

Golnhofer, E. (2006): Szervezeti kultúra. In: Golnhofer, E. (szerk.): A gyakorlati pedagógia néhány alapkérdése - Az iskolák belső világa. ELTE PPK Neveléstudományi Intézet, Budapest.

Graff, N. (2011): „An Effective and AgonizingWaytoLearn”. Backwards Design and New Teachers Preparation forPlanning Curriculum. Teacher Education Quarterly. 38/3. 151-168.

Handy, C. - Aitken, R (1990): Understanding Schools as Organizations. London, Pengvin Books Ltd.

Hegedűs, J. - Podráczky, J. (2012): Fókuszcsoportos beszélgetések a közoktatási intézmény és a család kapcsolatáról - első reflexiók a kutatás kapcsán. In: Szövetségben Tanulmányok a család és az intézményes nevelés kapcsolatáról. ELTE Eötvös Kiadó, Budapest. (105-123.)

Hofstede, G. (1991): Cultures and Organization. London, Mc-Graw Hill Book Company. Hofstede, G. - Hofstede, G.: Kultúrák és szervezetek - Az elme szoftvere. (2008) McGrawHill, 2005, VHE Kft, Pécs.

Hoy, W. K. - Miskel, C. G. (1987): Educational Administration. New York. Random House.

Karlovitz, J. T. (2011): Iskolaszervezeti vázlatok. Neveléstudományi Egyesület, Budapest.

Komlósi, Á. (1987): Hallgatói szemlélet- és magatartásmód elemzése nevelési konfliktushelyzetekben. In: Komlósi, Á. - Tóthné Dudás, M. - Vastagh, Z. (szerk.): Pedagógiai szituációk a tanárképzésben. Tankönyvkiadó, Budapest. (53-75)

Molnár, E. K. (2015): A tanári tervezés tanulásának és tanításának vizsgálata. (Kézirat) Letöltés: 2017. február 4. Elérhető: http://ofi.hu/sites/default/files/attachments/a_ tanari_tervezes_tanulasanak_es_tanitasanak_vizsgalata.pdf

Nilssen, V. L. (2010): Guided Planning in First-Year StudentTeachers' Teaching. Scandinavian Journal of Educational Research, 2010/ 5. 431-449. https://doi.org/10.1080/00313831.2010.508909

Norman, P. J. (2011): Planning for What Kind of Teaching? Supporting Cooperating Teachers as Teachers of Planning. Teacher Education Quarterly, 2011/ 3. 49-68.

Ollé, J.: Az iskola mint szervezet. In: Golnhofer Erzsébet (szerk.): Az iskolák belső világa. A gyakorlati pedagógia alapkérdései. Bölcsész Konzorcium, Budapest, 2006. 13-28.

Perlusz, A. - Marton, E. - Glauber, A. - Podráczky, J. - F. Lassú, Zs. (2012): A szülőiskola partnerségre, a szülői bevonásra irányuló nemzetközi törekvések és gyakorlati megoldások. In: Szövetségben - Tanulmányok a család és az intézményes nevelés kapcsolatáról. ELTE Eötvös Kiadó, Budapest. (43-70) 
Podráczky, J. (2012): „Érdektelen szülők” - különböző nézőpontok. In: Szövetségben Tanulmányok a család és az intézményes nevelés kapcsolatáról. ELTE Eötvös Kiadó, Budapest. (125-141.)

Serföző, M. (2005): Az iskolák szervezeti kultúrája. In: Iskolakultúra. 2005/10.(70-83.)

Suplicz, S. (2007): A sikeresség szempontjából fontos jellemzők diákvélemények tükrében. In: Alkalmazott Pszichológia. 2007/1. 116-132.

Szekszárdi, J.: Az osztályfönöki tevékenység helyzete és fejlesztési feladatai. elérhető: http:// ofi.hu/az-osztalyfonoki-tevekenyseg-helyzete-es-fejlesztesi-feladatai Letöltés: 2017. február 5 .

Szivák, J. (2003): Hallgatók neveléssel kapcsolatos nézetei. In. Iskolakultúra. 2003/5. (88-96)

Woods, P. (1983): Sociology and the School. In Hergraves, D.: The Challenge of the School London, Routledge, Keagan, Paul.

Zagyváné Szűcs, I. (2019): A pedagógusok szakmai önértékelését befolyásoló tényezők, különös tekintettel a külső szakmai elvárásokra és a szakmai énhatékonyság személyes észlelésére. Doktori (PhD) értekezés, Eger pp. 35-36. 
Melléklet:

\begin{tabular}{|c|c|c|c|c|c|}
\hline szórás & $\stackrel{\infty}{0}$ & $\underset{\substack{\infty \\
\sim}}{\stackrel{\infty}{\sim}}$ & 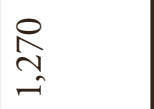 & $\stackrel{\widehat{\widehat{N}}}{=}$ & 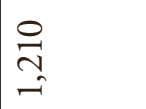 \\
\hline átlag & $\begin{array}{l}\stackrel{4}{ } \\
m \\
m\end{array}$ & 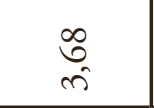 & $\begin{array}{l}\stackrel{0}{i} \\
i\end{array}$ & $\stackrel{\tilde{m}}{\tilde{n}}$ & $\stackrel{m}{\stackrel{m}{n}}$ \\
\hline $\begin{array}{r}5 \text { = inkább nem } \\
\text { értek egyet }\end{array}$ & $\hat{m}$ & $\bar{\infty}$ & $\bar{N}$ & $\stackrel{?}{f}$ & $\stackrel{\infty}{n}$ \\
\hline $\begin{array}{l}4=\text { inkább } \\
\text { egyetértek }\end{array}$ & $\infty$ & $\stackrel{n}{N}$ & $n$ & $\varpi$ & $\infty$ \\
\hline $\begin{array}{r}3=\text { egyet is értek, } \\
\text { meg nem is }\end{array}$ & $\pi$ & i & $\stackrel{m}{\wedge}$ & $\infty$ & in \\
\hline $\begin{array}{r}2=\text { inkább nem } \\
\text { értek egyet }\end{array}$ & $\approx$ & $n$ & 아 & ป & 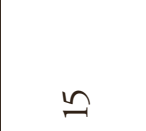 \\
\hline $\begin{array}{r}1 \text { = egyáltalán } \\
\text { nem értek egyet }\end{array}$ & 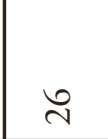 & $\stackrel{\sim}{\sim}$ & $\stackrel{\infty}{n}$ & $\stackrel{+}{m}$ & $\vec{N}$ \\
\hline $\begin{array}{l}\stackrel{\text { Af }}{\mathrm{N}} \\
\mathrm{Z}\end{array}$ & 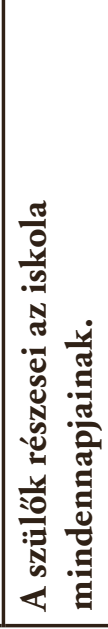 & 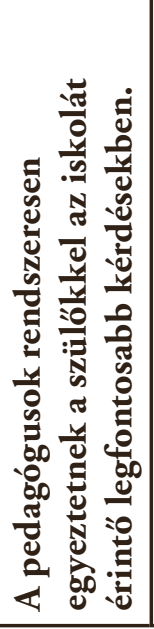 & 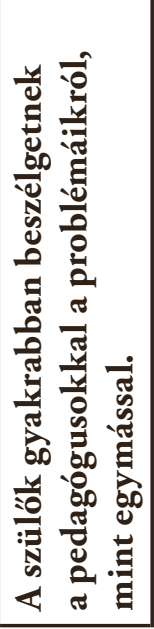 & 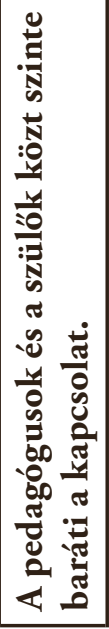 & 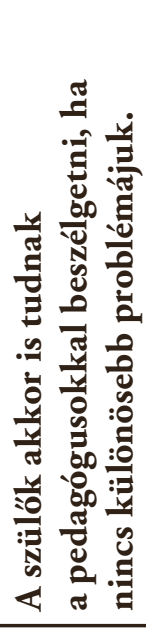 \\
\hline
\end{tabular}




\begin{tabular}{|c|c|c|c|c|c|c|c|c|}
\hline \multirow{2}{*}{\multicolumn{2}{|c|}{ 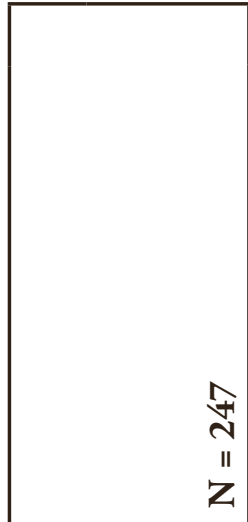 }} & \multicolumn{7}{|c|}{ Mely esetekben keresték meg Önt gyermeke pedagógusai? } \\
\hline & & 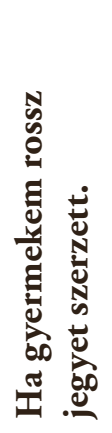 & 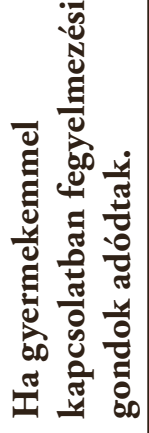 & 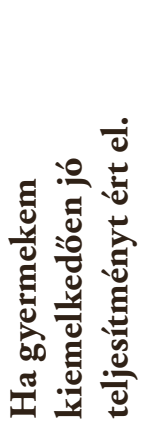 & 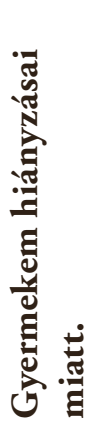 & 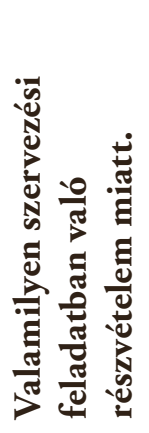 & 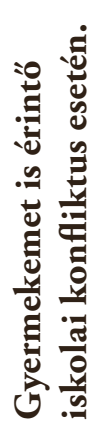 & 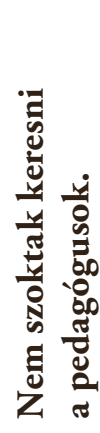 \\
\hline 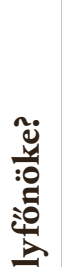 & 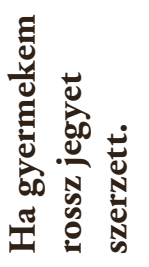 & હి & $\stackrel{n}{n}$ & $\infty$ & $\infty$ & $\Lambda$ & $\bullet$ & 요 \\
\hline 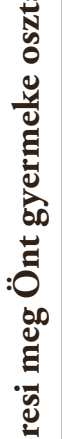 & 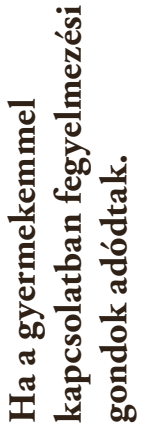 & $\exists$ & ป & $\curvearrowleft$ & $\Lambda$ & $\Lambda$ & $\stackrel{ }{-}$ & $\stackrel{+}{n}$ \\
\hline 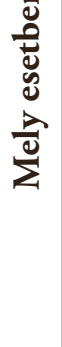 & 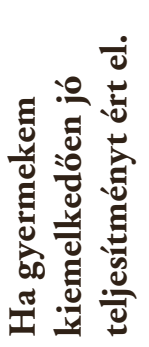 & $a$ & $\simeq$ & N & $n$ & $\nu$ & $\infty$ & 스 \\
\hline
\end{tabular}




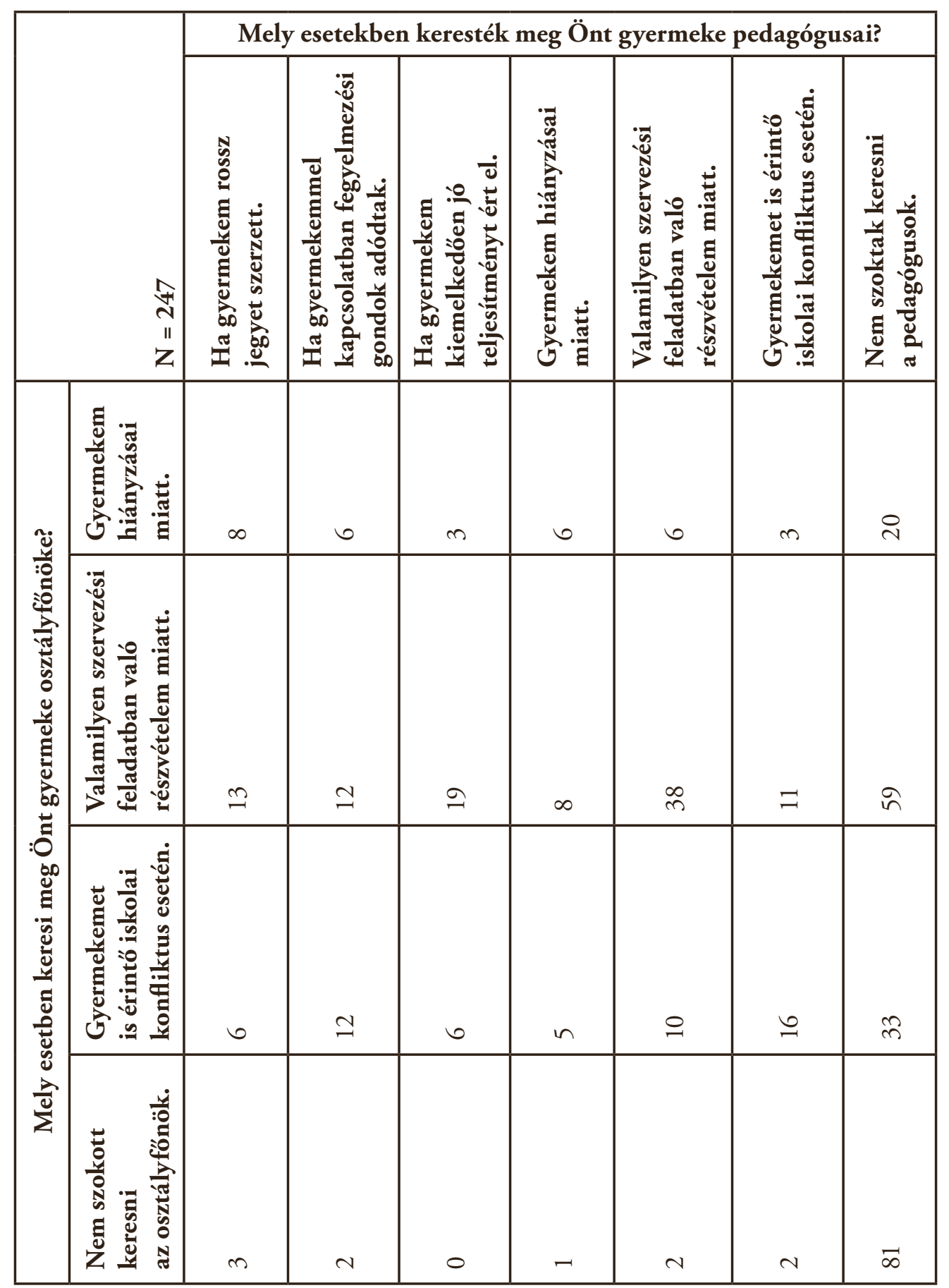

4.5. táblázat: Osztályfőnökök és pedagógusok megkeresési okainak együttes jelölése táblázat 


\begin{tabular}{|c|c|c|c|c|c|c|c|c|c|c|}
\hline \multirow{2}{*}{\multicolumn{2}{|c|}{$\begin{array}{l}\underset{1}{A} \\
\text { II } \\
\mathbf{Z}\end{array}$}} & \multicolumn{9}{|c|}{$\begin{array}{c}\text { Az alábbiak közül mely lehetőségeket használja Ön gyermeke } \\
\text { pedagógusaival való kapcsolattartásra? }\end{array}$} \\
\hline & & 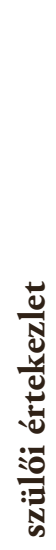 & 苟 & 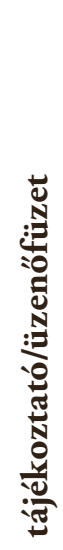 & 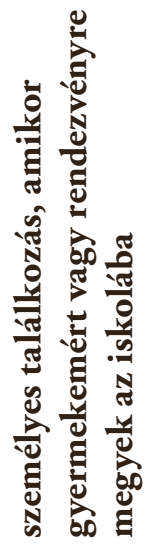 & 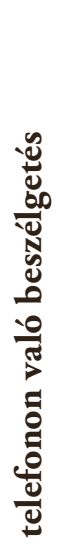 & 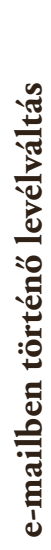 & 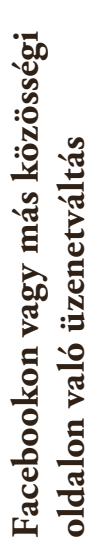 & $\begin{array}{l} \\
\\
\end{array}$ & 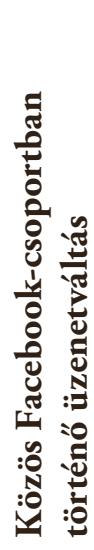 \\
\hline \multirow{4}{*}{ 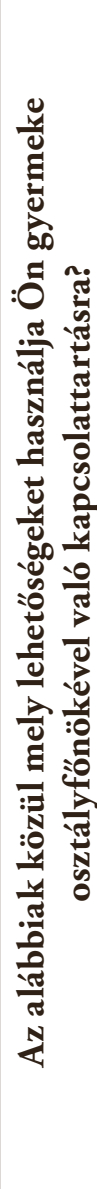 } & 总 & $\triangleq$ & $\Sigma$ & ๙ & $\infty$ & ৯े & $\stackrel{\infty}{m}$ & $\beth$ & $\stackrel{n}{=}$ & $\stackrel{\sim}{\sim}$ \\
\hline & 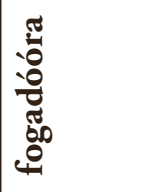 & $\infty$ & $\stackrel{\infty}{\curvearrowleft}$ & $\widetilde{\sigma}$ & 6 & $\stackrel{\downarrow}{\sim}$ & $\hat{n}$ & $\stackrel{n}{=}$ & $\stackrel{ }{\circ}$ & 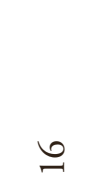 \\
\hline & 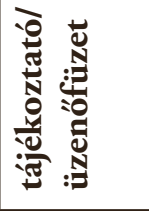 & $\mathbb{N}$ & ฉ & ゆ & $\stackrel{\infty}{n}$ & N & 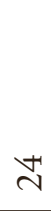 & $\mathcal{\simeq}$ & $\Lambda$ & $\stackrel{\infty}{\sim}$ \\
\hline & 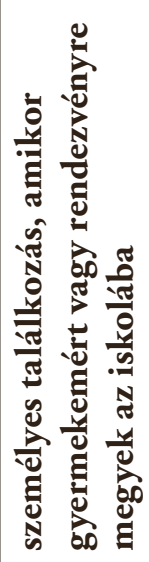 & $\stackrel{n}{N}$ & $\stackrel{\infty}{0}$ & ర్ర & $\infty$ & $\stackrel{\searrow}{\sim}$ & خे & $\stackrel{n}{=}$ & $a$ & $\stackrel{n}{\beth}$ \\
\hline
\end{tabular}




\begin{tabular}{|c|c|c|c|c|c|c|c|c|c|c|}
\hline \multirow{2}{*}{\multicolumn{2}{|c|}{$\stackrel{+}{\sim}$}} & \multicolumn{9}{|c|}{$\begin{array}{c}\text { Az alábbiak közül mely lehetőségeket használja Ön gyermeke } \\
\text { pedagógusaival való kapcsolattartásra? }\end{array}$} \\
\hline & & 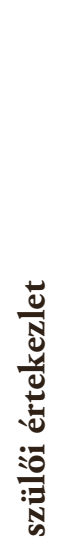 & 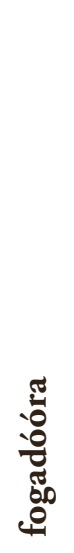 & 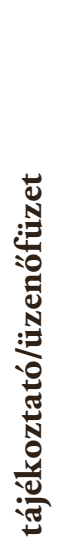 & 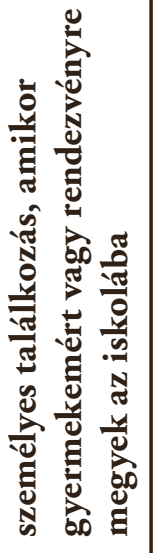 & 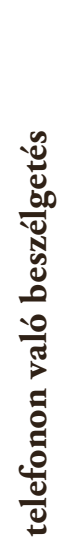 & 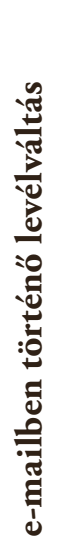 & 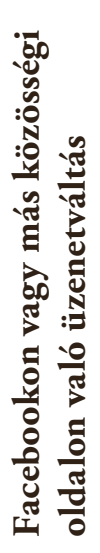 & 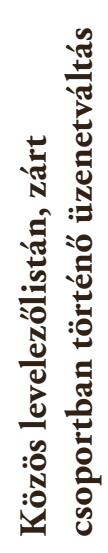 & 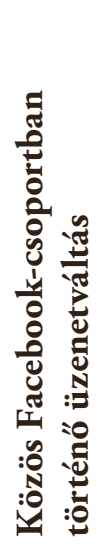 \\
\hline \multirow{3}{*}{ 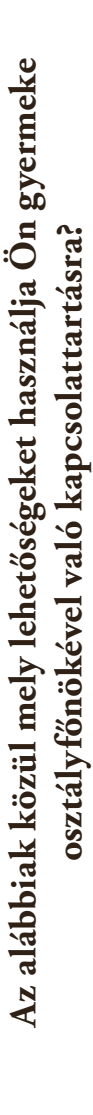 } & 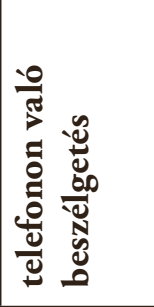 & $F$ & $\mathbb{N}$ & กี & $\stackrel{i}{n}$ & ปี & 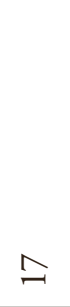 & $\sigma$ & $\checkmark$ & $\wedge$ \\
\hline & 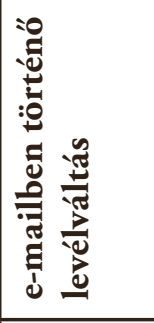 & $i n$ & $\infty$ & Fे & fr & ㄱ. & $\stackrel{\sim}{f}$ & $\stackrel{ }{-}$ & $=$ & $\Xi$ \\
\hline & 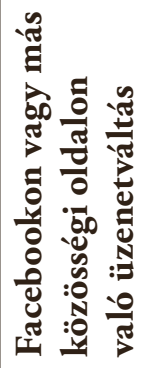 & $\widehat{\imath}$ & to & $\ddot{\sim}$ & $\tilde{N}$ & 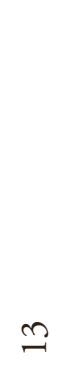 & $\stackrel{n}{n}$ & $\triangleq$ & $\wedge$ & \pm \\
\hline
\end{tabular}




\begin{tabular}{|c|c|c|c|c|c|c|c|c|c|c|}
\hline \multirow{2}{*}{\multicolumn{2}{|c|}{+1}} & \multicolumn{9}{|c|}{$\begin{array}{c}\text { Az alábbiak közül mely lehetőségeket használja Ön gyermeke } \\
\text { pedagógusaival való kapcsolattartásra? }\end{array}$} \\
\hline & & 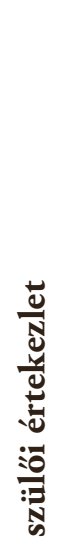 & 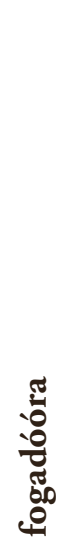 & 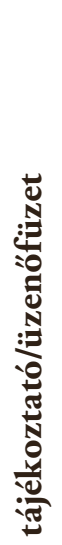 & 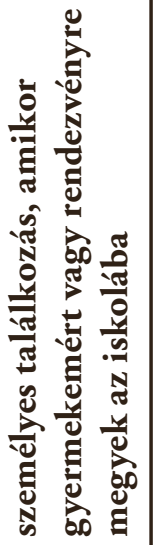 & 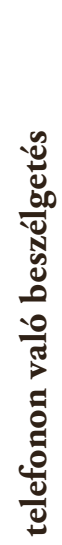 & 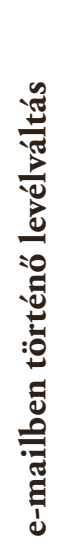 & 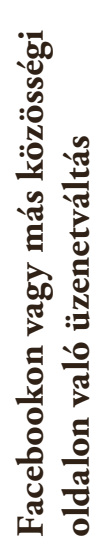 & 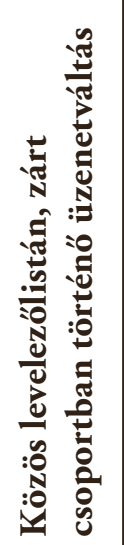 & 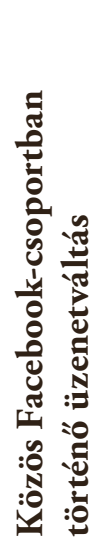 \\
\hline 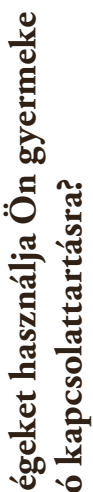 & 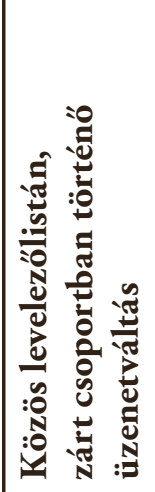 & กี & in & $\approx$ & 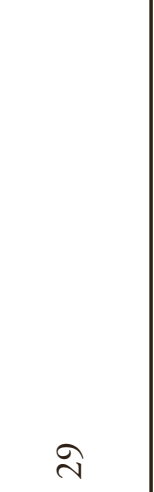 & $=$ & $\stackrel{0}{-}$ & $\wedge$ & $\stackrel{m}{\sim}$ & $\infty$ \\
\hline 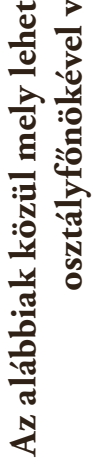 & 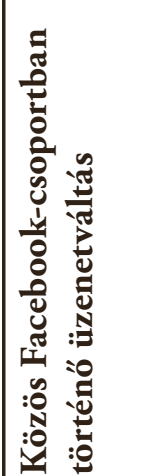 & $\stackrel{F}{f}$ & 8 & $m$ & $\stackrel{\infty}{\sim}$ & $\curvearrowleft$ & $\Xi$ & 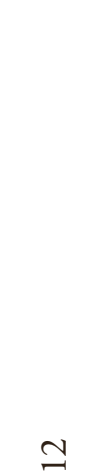 & $\wedge$ & $\vec{\lambda}$ \\
\hline
\end{tabular}

4.6. táblázat: Pedagógusokkal és osztályfőnökökkel történő kommunikáció egyidejü jelölési tendenciái szülőkk körében 


\begin{tabular}{|c|c|c|c|c|c|c|c|c|}
\hline & $\begin{array}{l}\text { N } \\
\text { II } \\
\mathbf{Z}\end{array}$ & 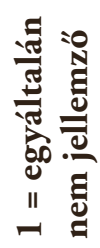 & 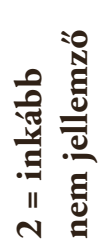 & 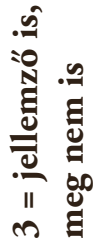 & 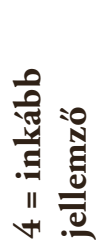 & 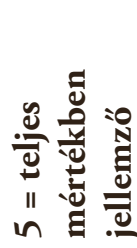 & $\underbrace{\infty}_{\pi}$ & 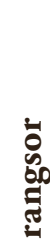 \\
\hline 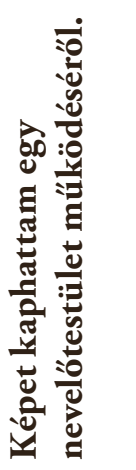 & & $a$ & 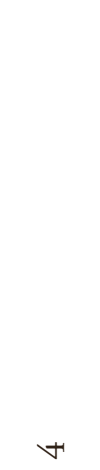 & $\forall$ & $n$ & N & $\begin{array}{l}0 \\
\infty \\
\text { i }\end{array}$ & $\dot{\sim}$ \\
\hline 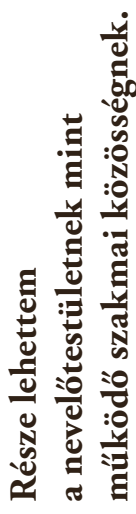 & & \pm & N & $n$ & 0 & - & $\stackrel{\mathbb{N}}{=}$ & $\dot{n}$ \\
\hline 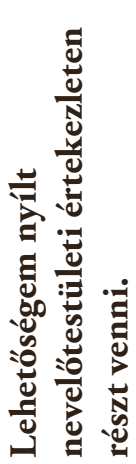 & & 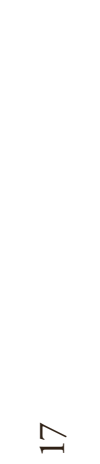 & - & 0 & $N$ & $N$ & $\underset{్}{\infty}$ & $\dot{0}$ \\
\hline
\end{tabular}




\begin{tabular}{|c|c|c|c|c|c|c|c|}
\hline $\begin{array}{c}\text { ป } \\
\text { ZI }\end{array}$ & 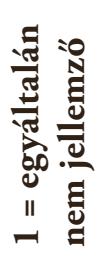 & 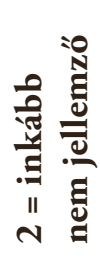 & 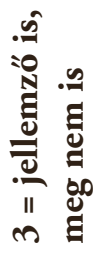 & 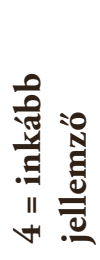 & 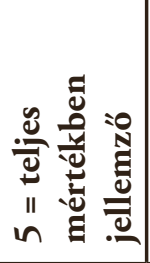 & $\frac{60}{\pi}$ & 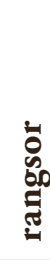 \\
\hline 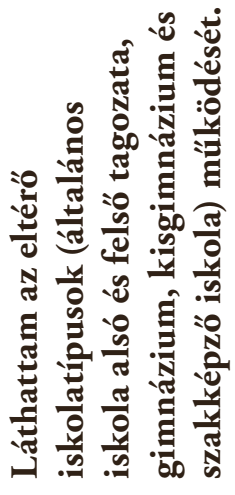 & $n$ & $\neg$ & $n$ & 6 & $n$ & ָ̃ & $-\dot{ }$ \\
\hline 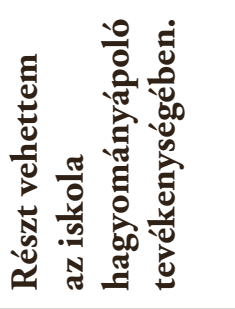 & $a$ & $N$ & $n$ & $\checkmark$ & $\checkmark$ & $\begin{array}{l}\tilde{\sigma} \\
i\end{array}$ & $\dot{r}$ \\
\hline 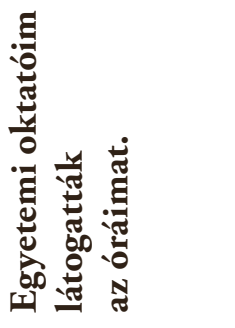 & $\Lambda$ & $\Lambda$ & $N$ & $\sim$ & $\checkmark$ & $\frac{n}{2}$ & $\forall \dot{~}$ \\
\hline 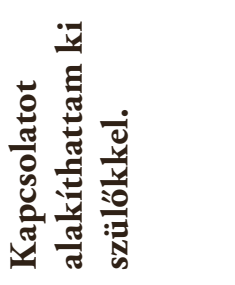 & $\supseteq$ & $n$ & 0 & 0 & 0 & $\stackrel{n}{=}$ & $\dot{\sim}$ \\
\hline
\end{tabular}

4.7. táblázat: Tanárjelöltek bevonódásérzete a gyakorlóiskola müködésébe 